\title{
Weathering of PGE sulfides and Pt-Fe alloys in the Freetown Layered Complex, Sierra Leone
}

\author{
John F. W. Bowles ${ }^{1}$ - Saioa Suárez ${ }^{2,3}$ • Hazel M. Prichard ${ }^{2}$ • Peter C. Fisher ${ }^{2}$
}

Received: 12 April 2016 / Accepted: 5 December 2016/Published online: 20 January 2017

(C) The Author(s) 2017. This article is published with open access at Springerlink.com

\begin{abstract}
Fresh and weathered rocks and saprolite from Horizon B of the Freetown Layered Complex contain platinum-group minerals (PGM). The PGM in the fresh rocks are $1-7 \mu \mathrm{m}$ across, including cooperite $(\mathrm{PtS})$, isoferroplatinum $\left(\mathrm{Pt}_{3} \mathrm{Fe}\right)$, minor tetraferroplatinum ( $\left.\mathrm{PtFe}\right)$, tulameenite $\left(\mathrm{Pt}_{2} \mathrm{FeCu}\right)$, Os-bearing laurite $\left(\mathrm{RuS}_{2}\right)$, and other base metalsulfide (BMS)-bearing PGM. The weathered rocks contain fewer of those PGM but a high proportion of disordered $\mathrm{Cu}-( \pm \mathrm{Pd})$-bearing $\mathrm{Pt}-\mathrm{Fe}$ alloys. The saprolite hosts scarce, smaller $(1-3 \mu \mathrm{m})$ ordered $\mathrm{PtFe}$ and disordered $\mathrm{PtFe}_{3}$. The PtFe alloys became increasingly Fe rich as weathering proceeded. $\mathrm{Pt}-\mathrm{Fe}$ oxides appeared during weathering. Copper sulfides associated with the primary PGM and cooperite (with $<3 \% \mathrm{Pd}$ ) were destroyed to provide the minor $\mathrm{Cu}$ and $\mathrm{Pd}$ found in some of the disordered Pt-Fe alloys. Platinum- and Pd-bearing saprolites have retained the original rock fabric and, to a depth of about $2 \mathrm{~m}$, surround residual rocks that show progressive weathering (corestones). Ground water passing through the saprolite has transported Pt and Pd (and probably Au) in solution down slope into saprolite over unmineralized rocks. Transport is marked by changes in the $\mathrm{Pt} / \mathrm{Pd}$ ratio indicating
\end{abstract}

Hazel M. Prichard died 1 January 2017.

Editorial handling: M. Fiorentini

John F. W. Bowles

john.bowles@manchester.ac.uk

1 School of Earth and Environmental Sciences, University of Manchester, Manchester M13 9PL, UK

2 School of Earth and Ocean Sciences, Main College. Park Place, Cardiff University, Cardiff, Wales CF10 3AT, UK

3 Department of Mineralogy and Petrology, UPV/EHU, 48940, Leioa and Ikerbasque, 48011 Bilbao, Spain that the metals have moved independently. Palladium is present in marginally higher concentrations in the deeper saprolite than in the corestones suggesting some retention of $\mathrm{Pd}$ in the deeper saprolite. Platinum and $\mathrm{Pd}$ are less concentrated in the upper saprolite than the deeper saprolite indicating surface leaching. Alteration occurred over a long period in an organic and microbial rich environment that may have contributed to the leaching and transport of PGE.

Keywords Platinum-group minerals · Freetown intrusion · Sierra Leone $\cdot$ Weathering $\cdot$ Mobility of platinum and palladium

\section{Introduction}

Platinum-group minerals (PGM) have been known in eluvial and alluvial deposits from the Freetown Layered Intrusion in Sierra Leone, West Africa, since 1926 and have been extracted from streams draining westwards into the Atlantic (Junner 1929, 1930; Junner and Harwood 1930; Pollett 1931, 1951).

The weathered covering of the Freetown intrusion consists of low-grade bauxitic laterites with the development of ferralitic soils and hard pans that are the result of intense weathering and erosion of the intrusion (Dixey 1920; Morel 1979). Erosion surfaces at 20-50 $\mathrm{m}$ and $190-210 \mathrm{~m}$ are shown in Fig. 1. They are considered to be wave-cut platforms cut into the rocks of the intrusion. Deposits at the base of the lower erosion surface contain Eocene fossils indicating that there has been erosion and weathering for at least $30 \mathrm{Ma}$ (Gregory 1952; Morel 1979). The current climate of the Freetown Peninsula is warm (typically $25-30^{\circ} \mathrm{C}$ all year) with a high rainfall of 3000-5000 $\mathrm{mm} /$ year due to the relief, proximity to the ocean, and onshore winds (Hughes and Hughes 1992). These conditions favor very active weathering under 


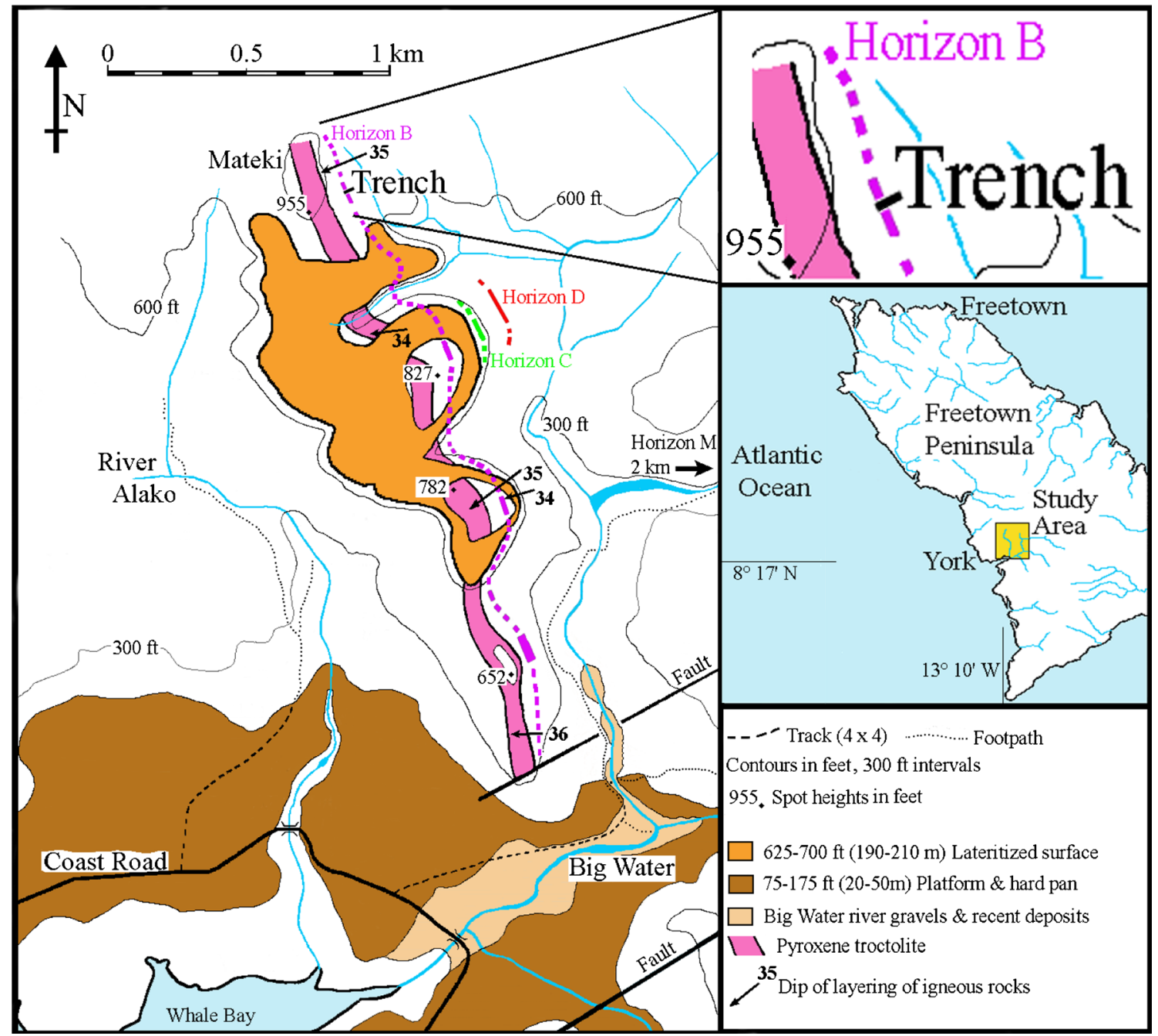

Fig. 1 Mateki Ridge, Freetown Peninsula, Sierra Leone, showing the positions of the PGE-bearing horizons and the trench sampled for this study

tropical rainforest conditions with saprolite developing during initial alteration of the igneous rocks.

The primary source of the alluvial PGM has been unknown until recently because the source rocks are obscured by the beach deposits, the hard pans, the deep weathering and the forest cover. Initial exploration campaigns in the watershed of the alluvial PGM deposits concluded that Pt was sparsely disseminated rather than confined to a single layer (Pollett 1931, 1951; Barber 1962). However, Bowles (2000b) has demonstrated the existence of PGE-bearing layers (up to $0.69 \mathrm{~g} / \mathrm{t} \mathrm{Pt}$; Fig. 1) describing, for the first time, stratiform primary sources for the PGM. These layers consist of magnetite-bearing gabbros that contain PGE mineralization associated with minor $\mathrm{Cu}$-rich and Ni-poor sulfides (Bowles et al. 2013).

The present study investigates the sequence of mineralogical modifications undergone by the primary PGEmineralization during weathering and erosion with a systematic survey of the PGM in: (i) fresh host rocks from the most PGE-enriched and best exposed igneous horizon, Horizon B, enlarging on the study by Bowles et al. (2013), (ii) adjacent weathered rock, and (iii) saprolite resulting from the in situ weathering of the horizons.

\section{Geology}

The Freetown Complex in Sierra Leone is a layered intrusion formed of mafic igneous rocks that outcrop to form an arcuate peninsula jutting out into the Atlantic (Wells 1962) for a strike length of $40 \mathrm{~km}$. Inland the rocks dip westwards at about $15^{\circ}$ and the dip increases to $40-50^{\circ}$ on the coast. Dated as $193 \mathrm{Ma}$, it was formed from multiple injections of mantle-derived magmas that intruded into the Archean rocks of the West African Shield during the initial rifting of the Atlantic Ocean (Wells 1962; Beckinsale et al. 1977; Chalokwu et al. 1995).

On land, the complex consists of a 7-km-thick sequence of gabbroic, troctolitic, and anorthositic rocks. A detailed description of the petrology and mineralogy is given in Wells (1962), Wells and Bowles (1981), Hargraves et al. (1999), Chalokwu et al. (1995), Bowles (2000b), and Bowles et al. (2013). The 
igneous layering is marked principally by variations in the proportion of olivine, plagioclase, and pyroxene with little change in mineral composition except at the four exposed PGE-bearing horizons (B, C, D, and M) described by Bowles (2000b) and Bowles et al. (2013). The latter paper used chondrite-normalized PGE analyses to indicate that the primary Freetown PGM resulted from magmatic concentration of the PGE from separate injections of geochemically distinct magma pulses.

The PGE horizons resemble the upper horizons in some other layered complexes (i.e., Skaergaard and Kap Edvard Holm in Greenland; Arnason and Bird 2000; Andersen 2006) that host PGE-bearing, Cu-rich, Ni-poor, generally Spoor, and Au-bearing mineralization often associated with magnetite and ilmenite. The mineralized horizons of the Freetown intrusion contain disseminated chalcopyrite, bornite, chalcocite, pentlandite, and pyrrhotite about $50 \mu \mathrm{m}$ in size with rare digenite and native copper up to $150 \mu \mathrm{m}$ across (Bowles 1978; Bowles et al. 2013). The primary PGM are typically associated with magnetite and occur as small grains $\leq 9 \mu \mathrm{m}$ in diameter within silicates and sulfides.

The PGE-bearing Horizon B occurs on a ridge formed by resistant pyroxenites that runs south from Mateki Hill which is inland from the village of York (Fig. 1). This horizon has been traced for over $5 \mathrm{~km}$, with a central section hidden by faulting, and it has consistent PGE assays along strike (Bowles 2000b). At Mateki, the ridge is drained to the west by the Alako river and to the east by the Big Water; platinum was recovered from both rivers during the alluvial working (Pollett 1931).

The present study focuses on fresh and weathered rock and saprolite samples all taken from a trench (Fig. 2a) dug across Horizon B to examine how the PGM alter during weathering. The trench was dug by hand using local labor. Apart from a few centimeters of humic top soil, the trench reveals saprolite containing remnant rocks and their weathered products known as corestones. The saprolite is crisp and easily dug by hand but collapses into a fine and evenly grained soil when disturbed. As each corestone was removed, the position was noted and the rock sampled for assay. Often the profile revealed by digging showed a concentric pattern around the corestone with about six bands, each $1-2 \mathrm{~cm}$ in width indicating in situ spheroidal weathering of the corestones. No clay horizon was observed. The saprolite contains a high proportion of gibbsite, and the location and weathering regime suggest that this is a ferralite (using the nomenclature of Duchaufour 1982).

\section{Samples and methods}

The trench (Fig. 2a) was dug across the stratigraphy and in sloping ground that rises gently to Mateki Ridge (Fig. 1) to the west and descends towards Big Water to the east, the slope becoming significantly steeper near the river. The trench is $20 \mathrm{~m}$ in length and $2 \mathrm{~m}$ deep and exposes the rocks of Horizon $\mathrm{B}$ and the footwall sequence stratigraphically beneath and downslope of Horizon B. It is limited at its western end by a substantial weathered outcrop (sample SC34, Table 1) that continues along strike for some tens of meters. Near the center of the trench, there is another weathered outcrop extending to the north but not to the south; it is revealed in the north wall of the trench and in the bottom of the trench (Figs. 2a and 3). Eight rock samples with weathered rims (Fig. 2b) and eleven saprolite samples from the trench are studied here. Additional assay results from eight rock samples and ten saprolite samples have also been used (Table 1).

The centers of corestones from the bottom of the trench contain the freshest material. There is a fresh to partially altered core with an outer weathered zone that is surrounded by
Fig. 2 a The trench. Saprolite profile drawn from field notes. $\mathbf{b}$ Cut surface of a corestone from the trench with scale in centimeters

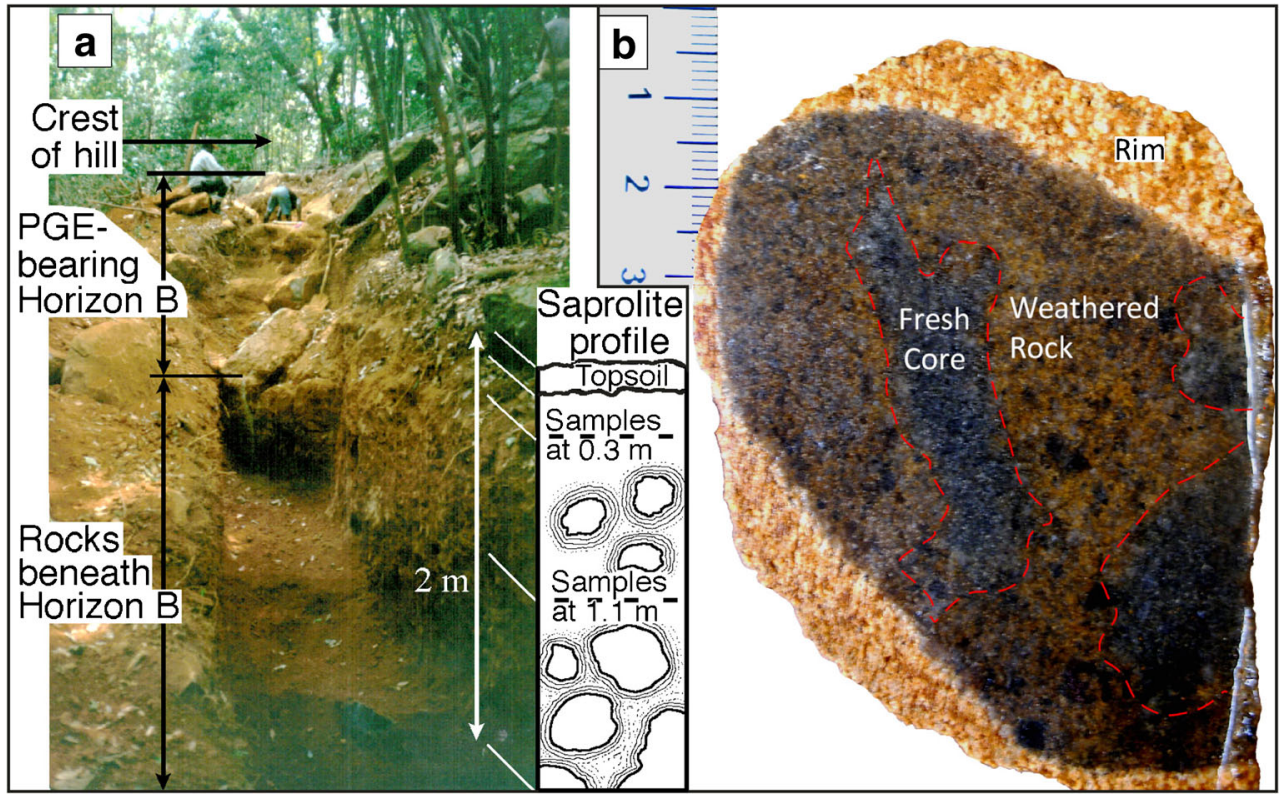


Table 1 Assays of the rock and saprolite samples arranged in stratigraphic order

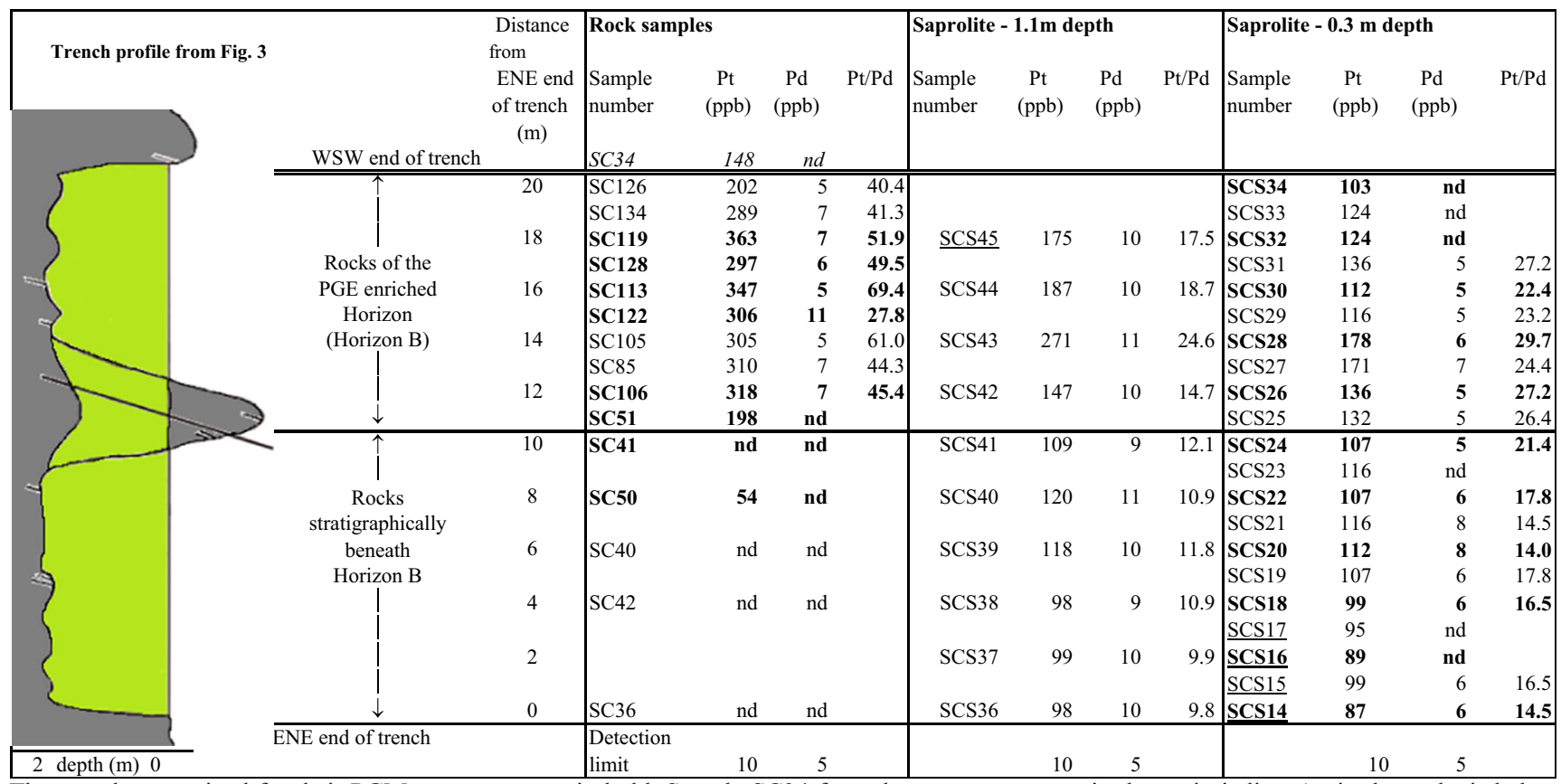

The samples examined for their PGM content are set in bold. Sample SC34 from the western outcrop is shown in italics. Au in the rocks is below detection (3 ppb). Saprolite samples SCS18-SCS34 and SCS36-SCS44 are below detection for Au (3 ppb)

Saprolite samples containing measurable Au (underlined) are SCS45 = 3 ppb, SCS14 = 3 ppb, SCS15 = 5 ppb, SCS16 = 3 ppb, and SCS17 = 9 ppb

$n d$ not detected

a 2-cm thick rim of strongly oxidized material (SC36 to SC134, Table 1; Fig. 2b).

Saprolite samples (SCS14 to SCS34, Table 1; Figs. 2a and 3) were collected at a depth of $30 \mathrm{~cm}$ along the northern wall of the trench. Samples SCS36 to SCS45 were collected from the same wall of the trench at a depth of $1.1 \mathrm{~m}$ (Table 1; Figs. 2a and 3). The saprolites are orange-brown and occur below a 10-cm-thick dark-brown top soil containing organic matter. The samples were sieved onsite using a standard $1.18 \mathrm{~mm}$ sieve. The saprolite is fine grained and passes readily through the sieve, the main purpose of the sieving being to remove the many fine roots.

Samples of the corestones and saprolite were sent to OMAC in Ireland for Pt, Pd, and Au assay, which was carried out by fire assay with an ICP finish (Table 1). X-ray diffraction analyses were carried out on both the saprolite samples and the oxidized rims of the corestones to study their overall mineralogy using a PANalytical Xpert PRO powder diffractometer with $\mathrm{Cu}-\mathrm{K} \alpha$ radiation at the SGIker facility, University of the Basque Country.

The samples were examined for their overall mineral and PGM content by scanning electron microscopy (SEM). Subsamples $(\sim 300 \mathrm{~g})$ of each saprolite SCS14 to SCS34 (Table 1) were sieved into six size fractions $(0-63-125-250$ 500-1000-1800 $\mu \mathrm{m})$. The fractions from the saprolite sample with the highest Pt (SCS28, Table 1) were searched, and PGM were found only in the finest fraction. This study used a Veeco FEI/Philips XL30 field emission gun environmental SEM fitted with an Oxford Instruments Inca Energy-Dispersive X-ray
(EDX) analysis system at Cardiff University. Operating conditions for qualitative analyses were $20 \mathrm{kV}$, with a specimen current of $\sim 1 \mathrm{nA}$, a working distance of $10 \mathrm{~mm}$, and a counting live time of $50 \mathrm{~s}$. Repeat analyses were performed on the PGM both to confirm the repeatability and to form a view on whether the minor element contents are the result of interference from surrounding minerals.

\section{Mineralogy of corestones and saprolite from the trench}

The fresh centers of the corestones are composed of mediumgrained Ca-rich plagioclase, olivine, clinopyroxene (diopside and augite), scarce orthopyroxene (enstatite and hypersthene), and late calcic amphiboles, phlogopite, chlorite, and quartz. Accessory phases include several generations of Ti-magnetite and ilmenite (Bowles 1977), base metal sulfides, rutile, and zircon. The few sulfides occur interstitially among the silicates and are chalcopyrite with exsolution of bornite and inclusions of digenite and bravoite. Pyrite, sparse pyrrhotite, pentlandite, chalcocite, galena, and sphalerite are also present. The centers of the corestones have irregular, gradational margins that give way to a slightly weathered, brown-ochre-colored zone (Fig. 2b).

The weathered rocks are characterized by a subtle alteration of silicates and a progressive deposition of fine-grained $\mathrm{Al}-(\mathrm{Fe}-\mathrm{Si})$ oxyhydroxides along inter-crystalline spaces. Segregations of 
Fig. 3 The trench. a Platinum assays of rocks (red) and saprolite (blue). Field details of igneous layering shown in black. Green indicates the materiel excavated. b Palladium assays of rocks (purple) and saprolite (orange). Vertical exaggeration $\times 2$

\section{a Pt assays (rock and saprolite) and stratigraphy}

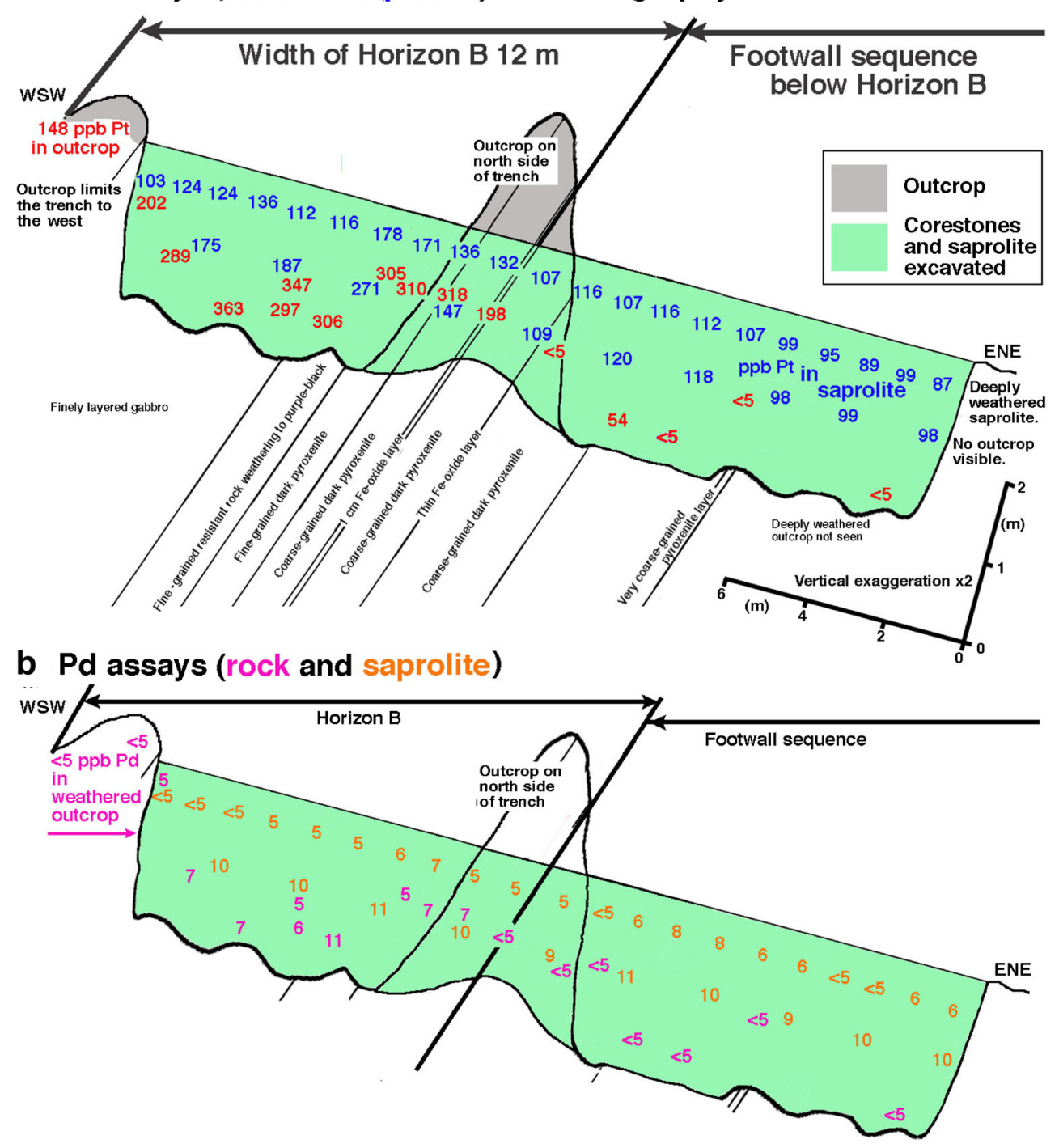

gibbsite containing traces of $\mathrm{Fe}$ and $\mathrm{Si}(\leq 1 \mathrm{wt} . \%)$ and boehmite are usual. Kaolinite halos may develop from feldspars whereas sulfides and spinels are generally well preserved.

The distinct orange-colored rims to the corestones are due to intense weathering and consist of coarse skeletal structures that are supported mainly by gibbsite and limonite with fine-grained quartz, goethite, hematite, and kaolinite. The secondary minerals denote an extensive dissolution of the silicates and an increase in the proportions of Fe and Si. The secondary Fe minerals contain significant amounts of $\mathrm{Si}$ and $\mathrm{Al}$ (up to 16 and $11 \mathrm{wt} \%$, respectively) and traces of $\mathrm{Mg}, \mathrm{Ca}$, or Ti. Goethite (replacing sulfides) retains $\mathrm{Cu}, \mathrm{Ni}$, and $\mathrm{Co}$ (up to $9 \mathrm{wt} \%$ in total). The footwall rocks are less resistant to erosion, and the alteration has produced a matrix in the weathered rims that often contains compact aggregates of kaolinite and quartz, perhaps indicating a local conversion of gibbsite to kaolinite during more extensive weathering.

Further physicochemical alteration of the rocks in an acid, high Eh weathering regime, has resulted in an orange-brown saprolite with a sandy loam texture. The saprolite aggregates are formed by a cryptocrystalline $\mathrm{Al}-\mathrm{Fe}-\mathrm{Si}$-rich groundmass enclosing fragments of inherited crystals (5-7\% of the sample) usually less than $50 \mu \mathrm{m}$ in size. The saprolite is composed mostly of gibbsite, quartz, kaolinite, and Fe oxides. Common residual accessory minerals are ilmenite, rutile, zircon, baddeleyite, and barite. Pyrite and chalcopyrite occur rarely.

\section{Mineralogy and occurrence of the PGM}

Ninety-seven PGM grains between 0.1 and $7 \mu \mathrm{m}$ across have been located during this study (Table 2; Fig. 4). Most are in the fresh and slightly weathered corestones whereas they are less well preserved in the highly weathered rims. Only four grains were located in the saprolites. The majority of the PGM are cooperite $(\mathrm{PtS})$ and $\mathrm{Pt}-\mathrm{Fe}$ alloys with compositions ranging from isoferroplatinum $\left(\mathrm{Pt}_{3} \mathrm{Fe}\right)$ to tetraferroplatinum $(\mathrm{PtFe})$. 
Table 2 Platinum-group minerals and their distribution through the weathered sequence

\begin{tabular}{|c|c|c|c|c|c|c|c|c|c|c|c|c|c|c|c|}
\hline & \multicolumn{3}{|c|}{ Horizon $\mathrm{B}^{\mathrm{a}}$} & \multicolumn{12}{|c|}{ Trench samples (minerals located during this study) } \\
\hline & \multicolumn{3}{|c|}{ Data from Bowles et al. (2013) } & \multicolumn{3}{|c|}{ Fresh rock } & \multicolumn{3}{|c|}{ Weathered rock } & \multicolumn{3}{|c|}{ Weathered rim } & \multicolumn{3}{|c|}{ Saprolite } \\
\hline No. of samples & 15 & & & 8 & & & 8 & & & 8 & & & 11 & & \\
\hline No. of sections & 51 & & & 13 & & & 13 & & & 13 & & & 16 & & \\
\hline No. of PGM grains & 107 & & & 37 & & & 40 & & & 16 & & & 4 & & \\
\hline Size range $(\mu \mathrm{m})$ & 0.1 & - & 7.4 & 0.1 & - & 7 & 0.3 & - & 4.1 & 1 & - & 3 & 1 & - & 2.9 \\
\hline Area $\left(\mu \mathrm{m}^{2}\right)$ & & & 325.8 & & & 93.9 & & & 108.1 & & & 35.9 & & & 15.9 \\
\hline Percentage PGE seen ${ }^{\mathrm{b}}$ & & & & & & 77 & & & 35 & & & 15 & & & 9 \\
\hline Types of PGM & No. & $\%$ & Area $(\%)$ & No. & $\%$ & Area $(\%)$ & No. & $\%$ & Area (\%) & No. & $\%$ & Area (\%) & No. & $\%$ & Area $(\%)$ \\
\hline PtS-PdS & 14 & 13.1 & 17.6 & 17 & 46.0 & 33.3 & 12 & 30.0 & 32.9 & 3 & 18.8 & 17.7 & - & - & \\
\hline Pt-Rh-Ir \pm BM sulfide & 10 & 9.3 & 1.7 & 3 & 8.1 & 6.8 & 1 & 2.5 & 1.3 & 2 & 12.5 & 6.8 & - & - & \\
\hline $\mathrm{RuS}_{2}$ & 3 & 2.8 & 0.4 & 3 & 8.1 & 1.5 & 1 & 2.5 & 0.2 & - & - & - & - & - & \\
\hline Pd-Pt-PGM & 6 & 5.6 & 4.3 & - & - & - & - & - & - & - & - & - & - & - & \\
\hline Ordered $\mathrm{Pt}_{3} \mathrm{Fe}$ & 72 & 67.3 & 74.8 & 7 & 18.9 & 25.5 & 9 & 25.0 & 25.1 & 2 & 12.5 & 23.6 & - & - & \\
\hline Disordered $\mathrm{Pt}_{3} \mathrm{Fe}$ & & & & 3 & 8.1 & 14.0 & 4 & 7.5 & 5.3 & 2 & 12.5 & 12.4 & 1 & 25 & 37.9 \\
\hline Disordered $\mathrm{PtFe}(\mathrm{Fe}<\mathrm{Pt})$ & & & & - & - & - & 5 & 10.0 & 12.1 & - & - & - & - & - & \\
\hline Ordered PtFe & & & & 1 & 2.7 & 6.7 & 2 & 7.5 & 9.3 & 2 & 12.5 & 19.3 & 1 & 25 & 40.4 \\
\hline Disordered $\mathrm{PtFe}(\mathrm{Fe}>\mathrm{Pt})$ & & & & - & - & - & - & - & - & - & - & - & - & - & \\
\hline Disordered $\mathrm{PtFe}_{3}$ & & & & - & - & - & - & - & - & 1 & 6.2 & 0.4 & 2 & 50 & 21.8 \\
\hline Disordered tulameenite & & & & 1 & 2.7 & 1.9 & 2 & 5.0 & 4.0 & - & - & - & - & - & \\
\hline Ordered tulameenite & 2 & 1.9 & 1.2 & 2 & 5.4 & 10.3 & 4 & 10.0 & 9.8 & 4 & 25.0 & 19.8 & - & - & \\
\hline
\end{tabular}

The division of the $\mathrm{Pt}-\mathrm{Fe}-\mathrm{Cu}$ alloys is described in the text and in Table 3

$B M$ base metals

${ }^{\mathrm{a}} \mathrm{Pt}_{3} \mathrm{Fe}, \mathrm{PtFe}$, and $\mathrm{PtFe}+\mathrm{Cu}$ not distinguished and listed here as ordered $\mathrm{Pt}_{3} \mathrm{Fe}$. This sample suite contained both fresh and weathered rocks

${ }^{\mathrm{b}}$ Percentage of the PGE found in assay accounted for by the PGM reported here. Approximate calculation uses (i) $r$ (grain radius assuming it is circular) $=\sqrt{ }($ area $/ \pi)$, (ii) volume $=4 \pi \mathrm{r}^{3} / 3$ (assuming grain to be spherical), (iii) mass of PGE $=$ volume $\times 0.5 / 10$ (where 10 is chosen to allow for the density and 0.5 for the proportion of PGE in the various PGM), (iv) mass of PGM/no. of sections, (v) mass of rock in section $=$ mass of section 2.5 by $4 \mathrm{~cm}$, a thickness of $3 \mu \mathrm{m}$, and a density of 2.5 , and (vi) calculated assay is mass of PGM/no. of sections $/$ mass of rock in section $=$ mass of section 2.5 by $4 \mathrm{~cm}$, a thickness of $3 \mu \mathrm{m}$, and a density of 2.5 . Result is calculated assay (vi) $\times 100 \% /$ average assay from Table 1

Some of the Pt-Fe alloys have a $\mathrm{Cu}$ content and may attain a composition close to tulameenite $\left(\mathrm{Pt}_{2} \mathrm{FeCu}\right)$. Accessory PGM are laurite $\left(\mathrm{RuS}_{2}\right)$, malanite $\left(\mathrm{CuPt}_{2} \mathrm{~S}_{4}\right)$, and a $\mathrm{Rh} \pm$ Pt-rich sulfide with a composition similar to bowieite $\left((\mathrm{Rh}, \mathrm{Ir}, \mathrm{Pt})_{2} \mathrm{~S}_{3}\right)$. The PGM proportions are illustrated in Fig. 5, and the results are consistent with previous observations (Bowles et al. 2013) as shown in Table 2.

The PGM are enclosed in silicates, sulfides, and secondary $\mathrm{Fe}-, \mathrm{Al}-$, or Si-rich oxides in equal proportions while a few PGM are enclosed within magnetite $(5 \%)$. In the fresh rocks, the PGM occur interstitially to primary silicates (clinopyroxene, feldspar, and olivine) and within late amphibole and chlorite. The most common sulfide-hosting PGM is chalcopyrite. Pentlandite and sphalerite are rare and infrequently contain PGM. The secondary phases hosting PGM are usually goethite derived from the oxidation of sulfides, $\mathrm{Fe}$ oxides after magnetite, and gibbsite, and they occur mainly in the weathered outer parts of the corestones.

There is a change in the mineralogy, composition, and textural features of the PGM with increased weathering of the corestones from center to rim and into the saprolite. The most abundant PGM in fresh rocks are $\mathrm{PtS}$ and $\mathrm{Pt}_{3} \mathrm{Fe}$ that typically occur as single euhedral grains within sulfides or silicates. The altered parts of the corestones contain more $\mathrm{Pt}-\mathrm{Fe} \pm \mathrm{Cu}$ alloys forming composite grains that are enclosed by $\mathrm{Fe}$ or $\mathrm{Al}$ oxyhydroxides. There is also a decrease in size of the PGM from center to rim, a trend that also continues into the saprolite (Table 2). Representative images of the PGM are shown in Fig. 4.

\section{Cooperite (PtS)}

Half of the cooperite found in this study occurs within the fresh rock cores (Table 2) where it is mainly enclosed in $\mathrm{Cu}$ sulfides or, in one case, in partially oxidized pentlandite. PtS within sulfides is usually subhedral to subrounded and is homogeneous in cross section. Less frequently, it is pitted (Fig. 4a) and can occur as irregular and elongate grains (Fig. 4b, c). Nearly half of the PtS grains occur on the edges of the sulfides. They often contain Ni but Pd is 

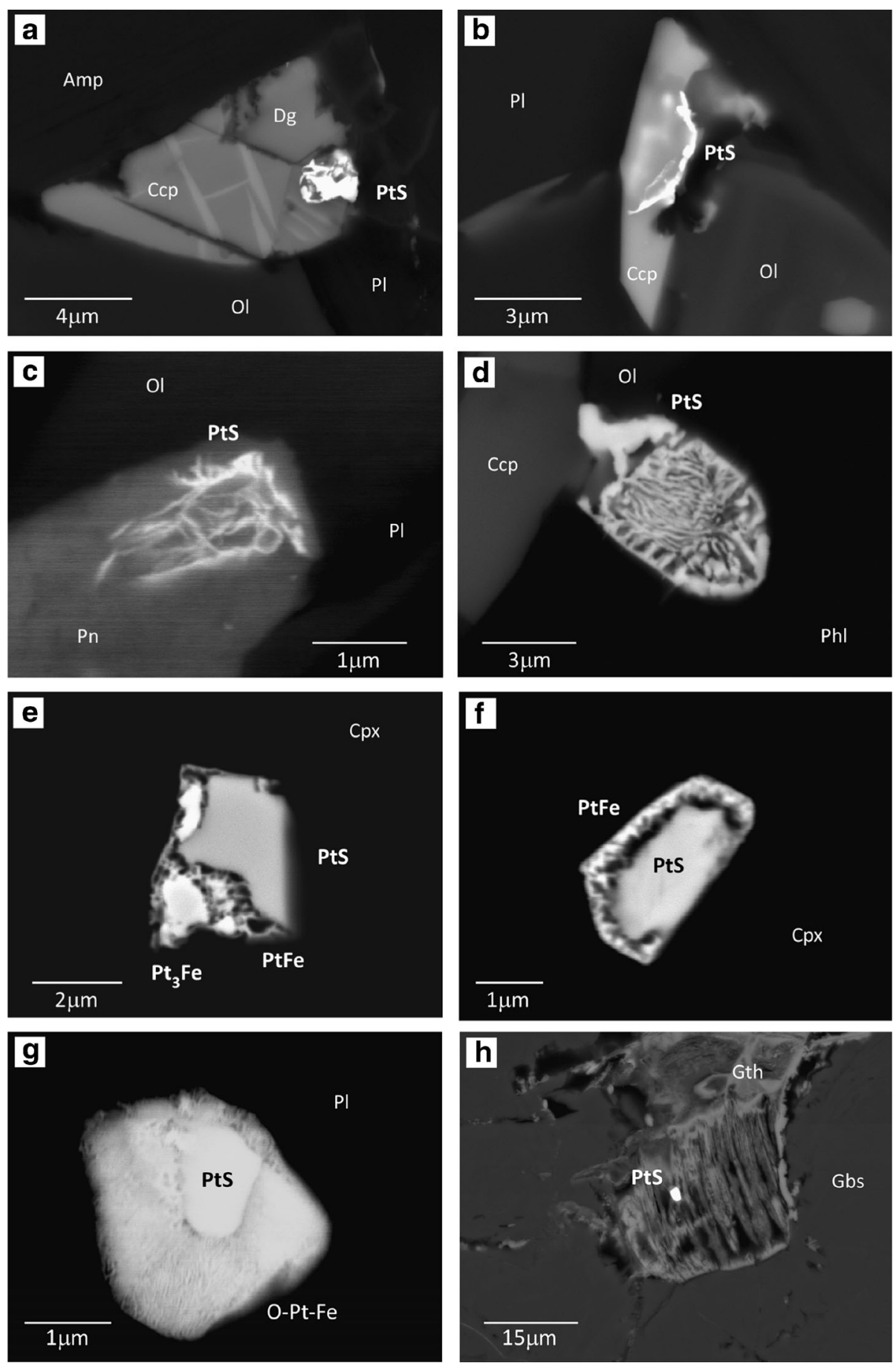

Fig. 4 Platinum-group minerals from fresh and weathered rocks and soils. a-d Ni-bearing cooperites $(P t S)$ within $\mathrm{Cu}-\mathrm{Fe}$ sulfides. The grains change from a subhedral and slightly pitted in the fresh cores to $\mathbf{b}, \mathbf{c}$ irregular elongate and $\mathbf{d}$ anhedral mottled grains in the weathered rocks. e A composite grain of $\mathrm{PtS}$ and isoferroplatinum $\left(\mathrm{Pt}_{3} \mathrm{Fe}\right)$ altered to a porous $\mathrm{Pt}-\mathrm{Fe}$ alloy at the silicate mineral boundary. f PtS partially pseudomorphed by a mottled tetraferroplatinum $(\mathrm{PtFe})$ and probably altered to a Pt-bearing oxide in the weathered rocks. $\mathbf{g}$ The relict core of an Fe-bearing PtS that has been altered at the contact with silicates in the weathered rocks. An oxygen content is recorded on the edges. $\mathbf{h}$ A small grain of PtS surviving in a relict silicate within the alteration rim of a boulder. $\mathbf{i}$ A group of $\mathrm{Pt}_{3} \mathrm{Fe}$ euhedral grains enclosed by chalcopyrite in

the fresh core. $\mathbf{j} \mathrm{Pt}_{3} \mathrm{Fe}$ with local development of a Pt-bearing oxide at the contact with silicates in a weathered boulder. $\mathbf{k}$ Mottled $\mathrm{Cu}$-bearing Pt-Fe alloy developed on the edges of $\mathrm{Pt}_{3} \mathrm{Fe}$ and adjacent to an osmian laurite, also seen as discrete grains (I) or on the edges of a tulameenite grain (m). n Relict tulameenite. o Euhedral $\mathrm{Pt}_{3} \mathrm{Fe}$ grain. p Irregular, poorly polished grains of $\mathrm{PtFe}$, both $(\mathbf{o}, \mathbf{p})$ embedded in the $\mathrm{Fe}$ oxides forming the soil aggregates. Abbreviations: Amp amphibole, Ccp chalcopyrite, $C h l$ chlorite, $C p x$ clinopyroxene, $D g$ digenite, Gbs gibbsite, Gth goethite, Hem hematite, Mag magnetite, $\mathrm{Ol}$ Olivine, ox. oxides, $\mathrm{Phl}$ phlogopite, $\mathrm{Pl}$ plagioclase, $\mathrm{Pn}$ pentlandite, $\mathrm{Pt}_{3} \mathrm{Fe}$ isoferroplatinum-type minerals, $P t F e$ tetraferroplatinum, $P t S$ cooperite 

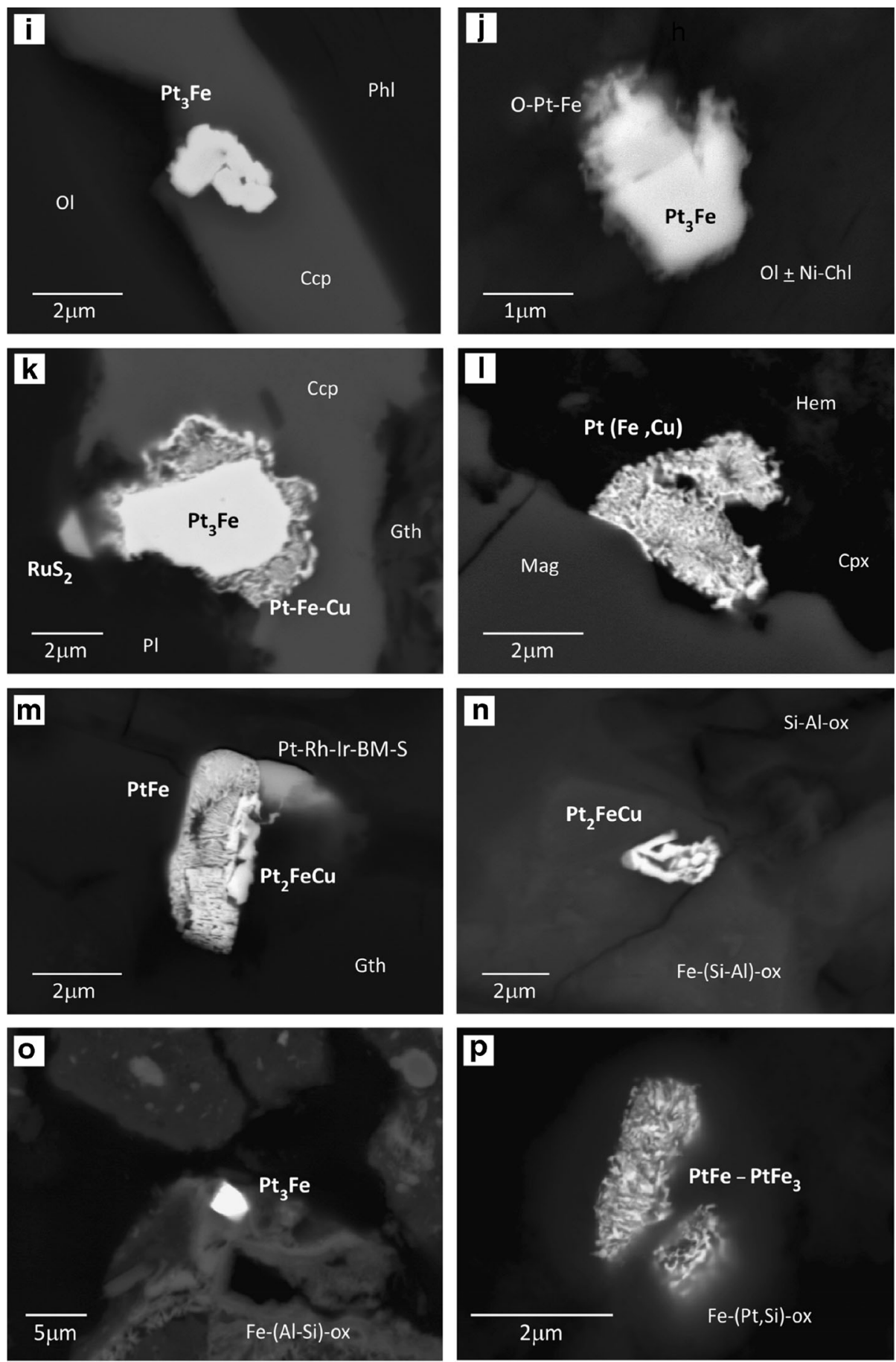

Fig. 4 (continued)

rarely present (up to $3 \mathrm{wt} \%$ in total). Other minor elements detected in the PtS are $\mathrm{Cu}$ and $\mathrm{Fe}(8$ wt.\%) although these could be an interference from the surrounding sulfides given the small grain size.

In the weathered part of the corestones, PtS associated with silicates shows mottled textures and may form composite grains with $\mathrm{Pt}-\mathrm{Fe}$ alloys (Fig. 4d-f).
Euhedral crystals of PtS occur partially pseudomorphed by $\mathrm{PtFe}$ on their edges (Fig. 4f). Grains within weathered plagioclase develop a distinctive altered edge of $\mathrm{Pt}-\mathrm{Fe}$ bearing oxide surrounding relict cores of $\mathrm{PtS}$ (Fig. 4g). Three grains of PtS have been located in the rims of the corestones, and all are small and subhedral $(<3 \mu \mathrm{m}$, Fig. $4 \mathrm{~h})$. 


\section{Fresh rock}

Ordered

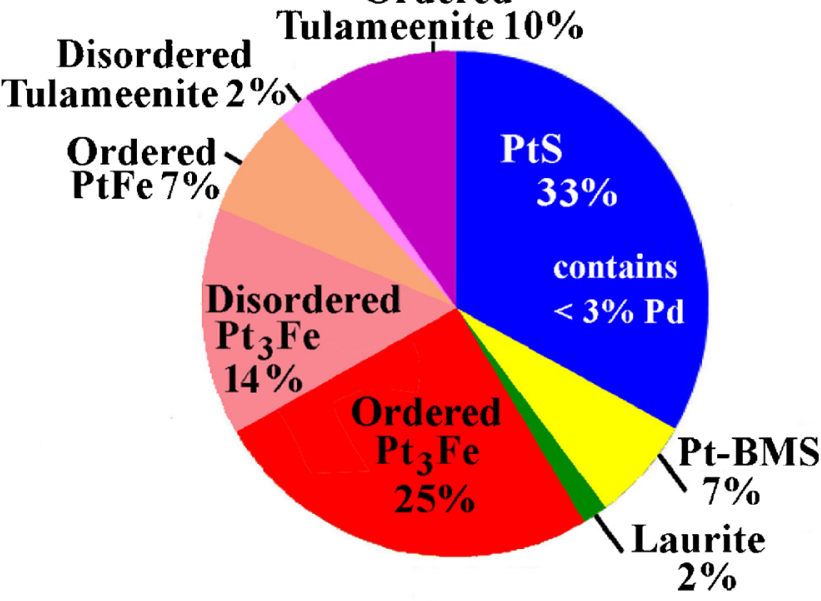

Very weathered rims

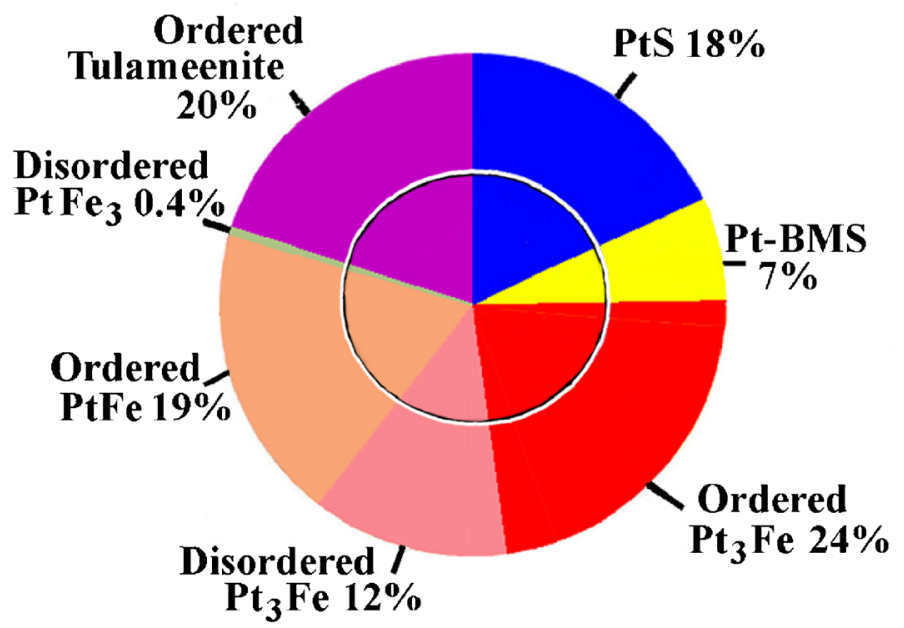

\section{Weathered rock}

\section{Ordered}

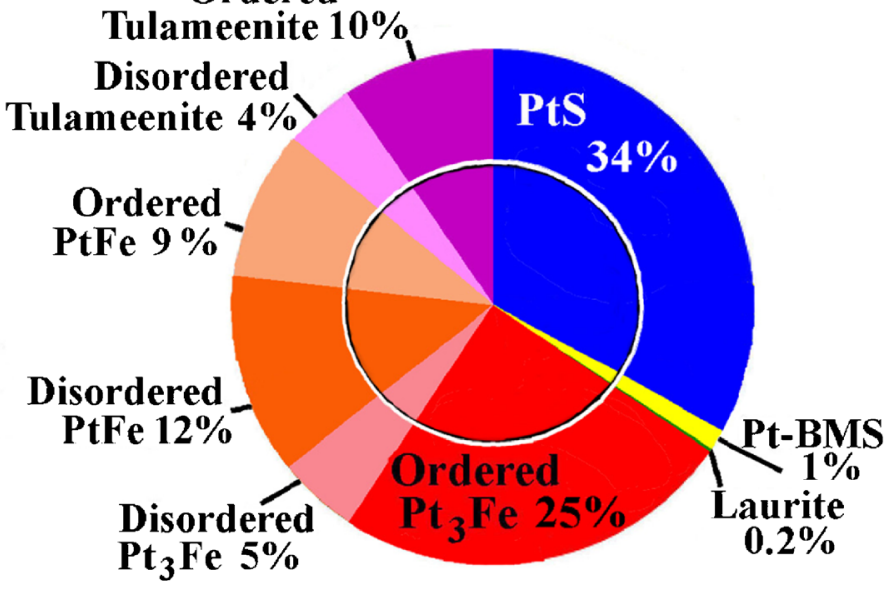

Saprolite

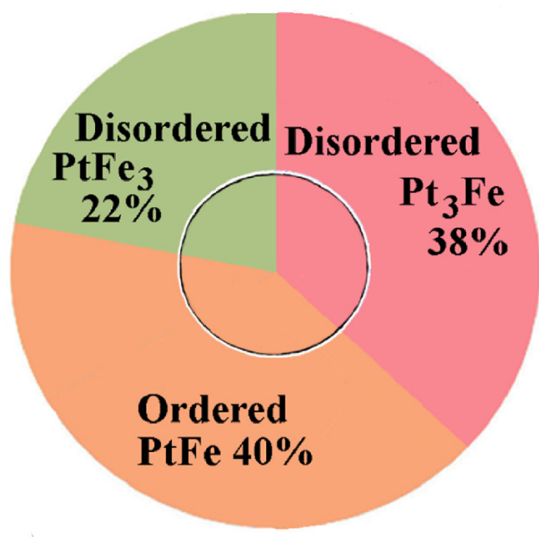

Fig. 5 Pie diagrams to show the development of the PGM species from the fresh rocks through the weathered rocks and into the saprolite. The inner circle indicates the area of the PGM reported in the weathered rocks and saprolite relative to the area of the PGM in the fresh rocks

\section{$\mathrm{Pt}-\mathrm{Fe} \pm \mathrm{Cu}$ alloys}

Most of the PGM in the rocks are Pt-Fe alloys exhibiting the wide compositional range described below and marked by variation in $\mathrm{Fe}$ and $\mathrm{Cu}$ (Fig. 6).

\section{Pt-Fe alloys}

Thirty-five $\mathrm{Pt}-\mathrm{Fe}$ alloys containing no $\mathrm{Cu}$ have compositions ranging from ideal $\mathrm{Pt}_{3} \mathrm{Fe}$ through $\mathrm{PtFe}$ (Figs. 5 and 6) towards $\mathrm{PtFe}_{3}$. $\mathrm{PtFe}$ in the fresh parts of the corestones forms composite grains with $\mathrm{PtS}$ and/or $\mathrm{Pt}_{3} \mathrm{Fe}(\mathrm{Fig}$. 4e,f,k) and usually displays pitted cores. In the weathered sections of the corestones, PtFe occurs in mottled grains with intergrown textures and irregular edges (Fig. 41). Rarely, PtFe appears in composite grains with $\mathrm{Pt}-\mathrm{Rh}$ sulfides, $\mathrm{Pt}_{3} \mathrm{Fe}$ or tulameenite (Fig. 4m). Four Pt-Fe alloys have been located in the saprolite samples from the trench overlying Horizon B where the highest $\mathrm{Pt}$ grades are recorded (samples SCS26 and SCS28, Table 1). These are less than $3 \mu \mathrm{m}$ in diameter and enclosed in $\mathrm{Fe} \pm \mathrm{Al}-(\mathrm{Si})$ aggregates. One euhedral grain is homogeneous with a composition near to $\mathrm{Pt}_{2.5} \mathrm{Fe}_{1.5}$ (Fig. 4o). The other three grains are closer to $\mathrm{PtFe}$ with compositions extending towards $\mathrm{PtFe}_{3}$ and have irregular and mottled surfaces (Fig. 4p). 


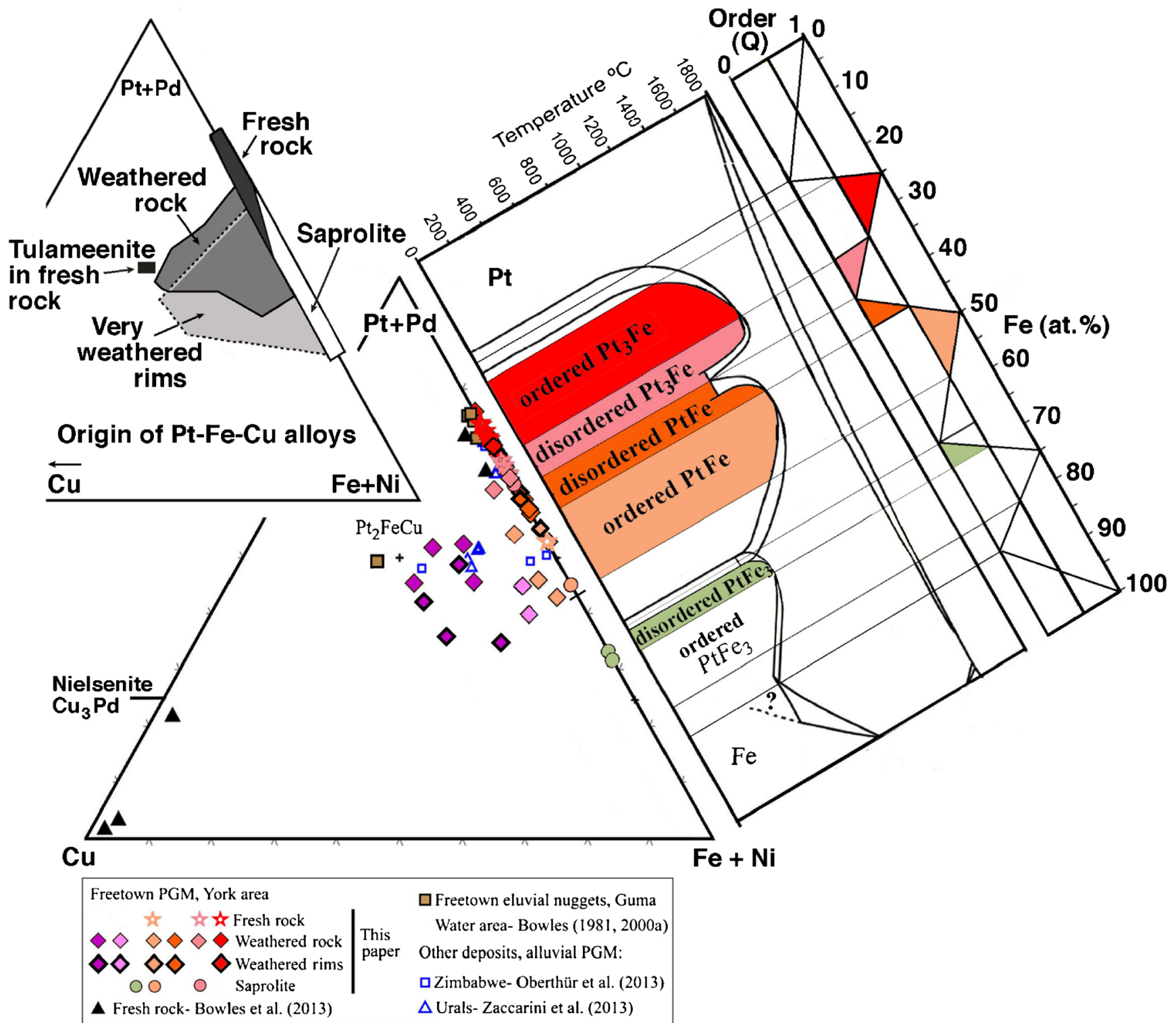

Fig. 6 Composition of $\mathrm{PGM}$ plotted in a triangular $(\mathrm{Pt}+\mathrm{Pd})-\mathrm{Cu}-(\mathrm{Fe}+$ $\mathrm{Ni}$ ) diagram with the $\mathrm{Pt}-\mathrm{Fe}-\mathrm{Cu}$ phase diagram of Okamoto (2004) and a schematic representation of the ordering $(Q)$ corresponding to Table 3 .

\section{$\mathrm{Pt}-\mathrm{Fe}-\mathrm{Cu}$ alloys}

Sixteen grains with $\mathrm{Cu}$ between 2 and 14.5 wt.\% fall in the compositional field between tetraferroplatinum and tulameenite $\left(\mathrm{Pt}_{2} \mathrm{FeCu}\right.$; Figs. 5 and 6). Tulameenite forms two solid solution series, one with ferronickelplatinum $\left(\mathrm{Pt}_{2} \mathrm{FeNi}\right.$; Rudashevsky et al. 1983) and another with PtFe (Shahmiri et al. 1986; Bowles 1990; Nixon et al. 1990). The ideal scheme of element substitutions requires an atomic $\mathrm{Pt} /(\mathrm{Fe}+\mathrm{Cu}+\mathrm{Ni})$ ratio of 1.0 for the members of the $\mathrm{Pt}_{2} \mathrm{FeCu}-\mathrm{PtFe}$ series although nonstoichiometric PGE-rich members have been reported (e.g., Tolstykh et al. 2002; Barkov et al. 2005). The atomic ratio observed for the $\mathrm{Pt}-\mathrm{Fe}-\mathrm{Cu}$ alloys studied here is $0.5-1.2$. Most $(80 \%)$ of these PGM have a composition closer to tulameenite,
The colors correspond to those in Fig. 5. The origins of the grains (fresh rock, weathered rock, highly weathered rim, or saprolite) are shown in the inset

ranging from $\mathrm{Pt}_{1.4}(\mathrm{Fe}, \mathrm{Cu})_{2.6}$ to $\mathrm{Pt}_{2.1}(\mathrm{Fe}, \mathrm{Cu})_{1.9}$. The other $\mathrm{Pt}-\mathrm{Fe}-$ $\mathrm{Cu}$ alloys are closer to tetraferroplatinum, from $\mathrm{Pt}_{0.9} \mathrm{Fe}_{1.1}$ to $\mathrm{Pt}_{1.1} \mathrm{Fe}_{0.9}$. Palladium has been detected in two grains ( $\left.<8 \mathrm{wt} . \%\right)$.

\section{Other PGM}

Rare PGM in the corestones $(n=10)$ consist of well-preserved PGE sulfides less than $3 \mu \mathrm{m}$ across. These include four grains of laurite $(\mathrm{Ru}, \mathrm{Os}) \mathrm{S}_{2}$ with a limited range of Os content (27$31 \mathrm{wt} . \%)$ and minor amounts of Pt. They are located in the fresh or slightly weathered parts of the corestones. These subrounded or euhedral grains lie close to grains of $\mathrm{PtS}$ or $\mathrm{Pt}_{3} \mathrm{Fe}$, within chalcopyrite that is interstitial to plagioclase or located between plagioclase and olivine (Fig. 4k). Three 
malanite grains occur $\left((\mathrm{Cu}, \mathrm{Fe})(\mathrm{Pt}, \mathrm{Rh}, \mathrm{Ir})_{2} \mathrm{~S}_{4}\right)$ with elevated $\mathrm{Rh}$ (average, $12.7 \mathrm{wt} \%$ ). One subhedral grain is enclosed by plagioclase in the center of a corestone close to chalcopyrite and $\mathrm{Pt}_{3} \mathrm{Fe}$ grains. Another two rounded grains lie within Fe oxides in the weathered part of the corestone and one is attached to a $\mathrm{Pt}-\mathrm{Fe}$ alloy (Fig. 4m). Three other grains are $\mathrm{Pt} \pm \mathrm{Rh}-\mathrm{Ir}$ sulfides with a composition close to bowieite, sometimes with an excess of Pt and S. Two of these are euhedral grains interstitial to silicates in the core of the rocks. The other grain is subhedral and occurs within a relict magnetite in a weathered rim.

\section{PGM textures and associations}

The textures and associations of these alloys vary and are summarized by a sketch (Fig. 7). Those with an intermediate $\mathrm{Pt}_{3} \mathrm{Fe}-\mathrm{PtFe}$ composition are located mainly in the centers and slightly weathered parts of the corestones and rarely in the rims. Normally, these are lath-shaped single grains, within either fresh $\mathrm{Cu}$ sulfides or Fe oxides. Sometimes, they occur in groups of several euhedral grains (Fig. 4i) or clustered with other PGM such as tetraferroplatinum, tulameenite, or laurite. Where hosted by silicates, the edges of the PGM grains are altered to $\mathrm{Pt}-\mathrm{Fe} \pm \mathrm{O}$ (Fig. $4 \mathrm{j}$ ) especially those that are close to grain boundaries with access to interstitial fluids. The alteration can include well-developed symplectic growths of $\mathrm{Pt}-$ $\mathrm{Fe} \pm \mathrm{Cu}$ (Fig. 4k). The more $\mathrm{Fe}$ - and $\mathrm{Cu}$-rich examples are mainly located in the more weathered corestones as shown by the inset to Fig. 6. These are subhedral to subrounded and occur enclosed in Fe oxides associated with sulfides or magnetite relicts, and they also occur rarely in clinopyroxenes.

Grains with a composition close to ideal $\mathrm{Pt}_{2} \mathrm{FeCu}$ occur mainly in the weathered parts of the corestones as isolated grains within secondary oxides. These tulameenites are $<3 \mu \mathrm{m}$ in diameter and display a fine intergrowth with planar edges and cuspate textures (Fig. 4n). One tulameenite forms a composite grain with symplectic Pt-Fe alloy and a PGE-BMS (Fig. $4 \mathrm{~m}$ ) and other $\mathrm{Cu}$-rich examples of symplectic growths have formed around isoferroplatinum in chalcopyrite (Fig. 4k) and on the edge of magnetite (Fig. 41).

$\mathrm{Pt}_{3} \mathrm{Fe}, \mathrm{PtFe}, \mathrm{Pt}_{2} \mathrm{FeCu}$, and intermediate compositions all show alteration textures. Relict cores of $\mathrm{Pt}_{3} \mathrm{Fe}$ and $\mathrm{PtS}$ are surrounded by alteration haloes of $\mathrm{PtFe}$ or $\mathrm{Pt}-\mathrm{Fe}$ oxide (Fig. 4g, j, k). A Pt-oxide stage may lie between PtS and PtFe (Fig. 4e, f, Bowles et al. 2013) with the PtS encased by a host

\section{FRESH ROCK}

\section{Coarse-grained primary silicates with interstitial chlorite, amphibole and quartz}
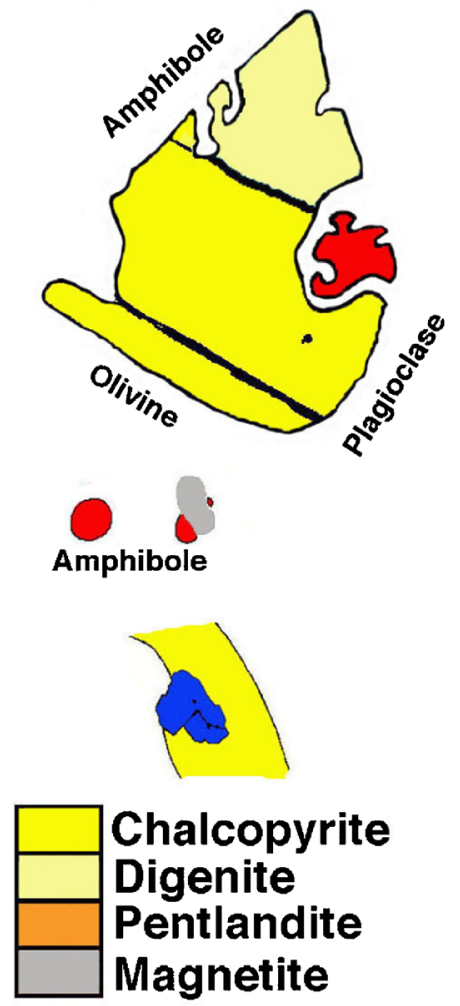

WEATHERED ROCK

Skeletal structures supported by gibbsite
SAPROLITE

Fine-grained Fe- and Aloxides and hydroxides in saprolitic aggregates

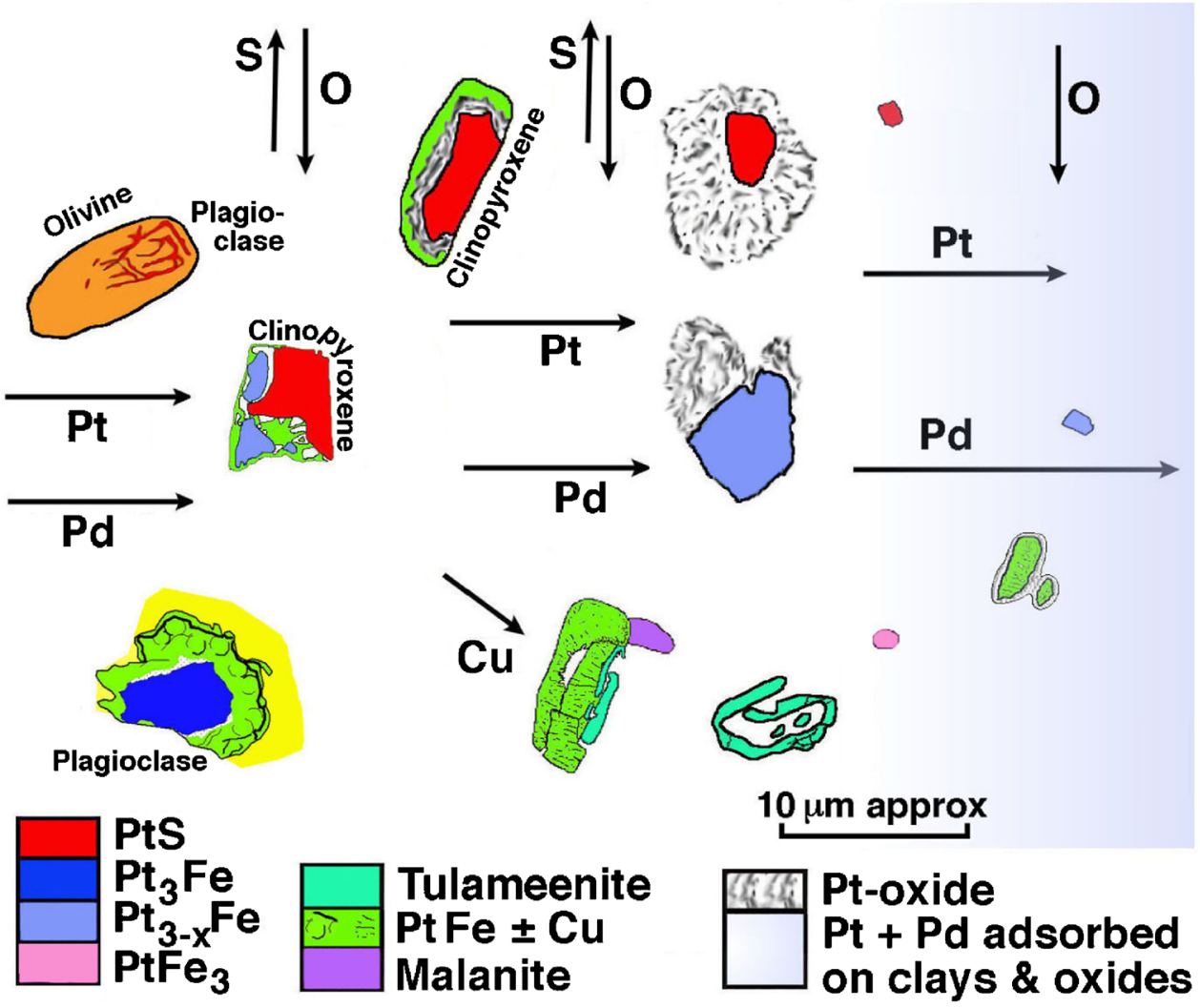

Fig. 7 Interpretation of the weathering of the PGM, drawn from the examples shown in Fig. 4 
sulfide or silicate and the altered PGM exposed to alteration by interstitial fluids. The textures could indicate that the PtS was altered to Pt oxide and then to PtFe, but it is more likely that PtS altered to PtFe due to sulfur loss and then Pt oxide formed later as fluids moved along the PtS boundary (Suárez et al. 2010; Bowles et al. 2013). Some PtS grains appear to be the source of Pt-rich filaments that extend into the host sulfide, indicating alteration of the PtS and redistribution of the Pt. This texture is particularly evident in Fig. 4c where a grain of PtS seems to be the source of an extensive network of filaments extending into the host pentlandite. Less-distinct Pt-rich filaments extend from PtS into the chalcopyrite host in Fig. 4b. Other PtS grains show a reaction to $\mathrm{Pt}$ oxide and $\mathrm{Pt}-\mathrm{Fe}$ alloy as a vermicular intergrowth with a symplectic texture surrounded by a more contiguous rim of $\mathrm{Pt}-\mathrm{Fe}$ alloy that appears to represent a reaction front (Fig. 4d-g). Grains of $\mathrm{Pt}_{3} \mathrm{Fe}$ can show slightly altered margins marked by small-scale filamentary outgrowths (Fig. 4j) or more extensive alteration with symplectic alteration of $\mathrm{Pt}-$ $\mathrm{Fe}-\mathrm{Cu}$ alloy terminating in a more contiguous rim (Fig 4k, l). In the saprolite, the symplectic intergrowths do not contain $\mathrm{Cu}$, the rim is absent and there is no obvious parent grain (Fig. 4p). Symplectic Pt-Fe alteration can also surround tulameenite (Fig. 4m). Similar symplectic intergrowths between Pt-Fe alloy and $\mathrm{Pt}-\mathrm{Fe}$ oxides of varying $\mathrm{Pt}-\mathrm{Fe}$ ratio have been reported from altered PGE mineralization in south-eastern New Caledonia (Augé and Legendre 1994). The grains described here show that this alteration typically occurs at boundaries between the host silicates or sulfides. For example, a homogeneous grain of cooperite is attached to chalcopyrite and the adjacent symplectic-altered PGM extends into secondary mica (Fig. 4d).

\section{Crystal structures in the system Pt-Fe}

The PGM assemblage described here contains a large variety of Pt-Fe alloys that can be related to a phase diagram. Versions of the Pt-Fe phase diagram appeared in Cabri and Feather (1975) and Bowles (1990). Subsequent work by Okamoto (1993), Osaka et al. (2002), and Nosé et al. (2003) confirmed the general form of the phase diagram but modified details of the $\mathrm{Pt}_{3} \mathrm{Fe}, \mathrm{PtFe}$, and $\mathrm{PtFe}_{3}$ fields, moving both the points of maximum temperature and the intervals between these fields to slightly more Pt-rich compositions. An assessment of the recent work by Okamoto (2004) recommends that the modified phase diagram (Fig. 6) be accepted as it is based on a larger number of experimental points with lower uncertainty.

Native Pt is cubic ( $F m 3 m, 0-17 \% \mathrm{Fe})$ with $a=3.9231 \AA$ for synthetic material. In natural examples, the addition of some $5 \% \mathrm{Fe}$ reduces this cell dimension to $3.877 \AA$ (Cabri and Feather 1975). With increasing Fe content, the structure between $17 \%$ and $20 \% \mathrm{Fe}$ is disordered or a mixture of native $\mathrm{Pt}$ and isoferroplatinum. Isoferroplatinum $\left(\mathrm{Pt}_{3} \mathrm{Fe}\right)$ has a cubic structure (Pm3m, 20-36\% Fe) with $a=3.86 \AA$ (Cabri and Feather 1975). The Fe in stoichiometric isoferroplatinum contributes 25 at. \% of the total mineral. Small variation in the $\mathrm{Fe}$ content leads to partial disorder. There is an interval between $36 \%$ and $41 \% \mathrm{Fe}$ where the structures are again disordered or isoferroplatinum and tetraferroplatinum can coexist (Evstigneeva 2009). Tetraferroplatinum $(\mathrm{PtFe})$ is tetragonal with $a=3.84 \AA, c=3.71 \AA(P 4 / \mathrm{mmm}, 41-65 \% \mathrm{Fe})$. Here, in the stoichiometric proportion, $\mathrm{Fe}$ represents 50 at.\% of the mineral. The tetragonal structure is necessary to accommodate the difference in ionic radius of $\mathrm{Fe}$ and $\mathrm{Pt}$ at these $\mathrm{Fe}$ concentrations. The change in composition between isoferroplatinum and tetraferroplatinum results in a small reduction in the cell dimension along two axes from 3.86 to $3.84 \AA$ and, along the third axis, from 3.86 to $3.71 \AA$. Adaptation of the structure to changes in composition is, therefore, small. Tulameenite $\left(\mathrm{Pt}_{2} \mathrm{FeCu}\right)$ is also tetragonal $(\mathrm{P} 4 / \mathrm{mmm})$. Quenched synthetic tulameenite adapts to disordering of the structure by multiple twinning showing fine herring-bone twinning or broader, parallel twins and dislocations (Shahmiri et al. 1986).

$\mathrm{Pt}-\mathrm{Fe}$ alloys with compositions between $\mathrm{Pt}_{3} \mathrm{Fe}$ and $\mathrm{PtFe}$ have been reported previously especially from placer deposits. Some examples are the Chocó region, Colombia (Cabri et al. 1996), the Aikora River Area, Papua New Guinea (Weiser and Bachmann 1999), the Great Dyke (Oberthür et al., 2003a, b, 2013), British Columbia, Canada (Barkov et al. 2005), Urals (Malitch and Thalhammer 2002; Evstigneeva 2009; Zaccarini et al. 2013), or Yubdo (Evstigneeva 2009). Malitch and Thalhammer (2002) and Evstigneeva (2009) discuss in detail whether the composition near $\mathrm{Pt}_{2} \mathrm{Fe}$ represents a new mineral phase, a fine intergrowth of $\mathrm{PtFe}$ and $\mathrm{Pt}_{3} \mathrm{Fe}$ (as suggested by Zhernovsky et al. 1985) or a disordered structure that is stable under particular conditions. The majority of the Pt-Fe alloys examined using XRD reveal a disordered cubic phase, but some studies confirm a micrometric intergrowth in two grains, both from the Nizhni Tagil placers (Evstigneeva 2009).

For the purpose of illustrating the process of alteration of the Freetown Pt-Fe alloys described here and shown on the pie diagram (Fig. 5) and on the phase diagram (Fig. 6), it will help to use an order parameter $(Q)$ defined as $Q=1$ for the ordered stoichiometric compositions $\left(\mathrm{Pt}_{3} \mathrm{Fe}, \mathrm{PtFe}\right.$, and $\mathrm{Pt}_{2} \mathrm{FeCu}$ ) and $Q=0$ for the points of maximum disorder in between these compositions taken as the mid-points of the disordered zones defined by the phase diagram. Values of $Q$ can be determined from the mineral compositions by allocating $\mathrm{Pt}, \mathrm{Fe}$, and $\mathrm{Cu}$ to their appropriate locations in the structure. Any $\mathrm{Pd}$ is included with $\mathrm{Pt}$ and minor $\mathrm{Cu}$ with $\mathrm{Fe}$. An arbitrary order of $Q=0.5$ is used to distinguish the ordered $(Q>0.5)$ and disordered $(Q<0.5)$ phases shown in Table 3. For this purpose, $\mathrm{PtFe}$ is calculated as $\mathrm{Pt}_{2} \mathrm{Fe}_{2}$ so that all the phases have 4 atoms/formula unit.

The compositions of the $\mathrm{Pt}-\mathrm{Fe}-\mathrm{Cu}$ alloys in the samples examined here show significant variation. The phase diagram for 
Table 3 Illustrative distinction of ordered and disordered $\mathrm{Pt}-\mathrm{Fe}-\mathrm{Cu}$ alloys

\begin{tabular}{llll}
\hline Ordered isoferroplatinum & $\mathrm{Pt}_{3} \mathrm{Fe}$ & $0.5>Q>1$ & $3.12>\mathrm{Pt}>2.68,0.88<\mathrm{Fe}+\mathrm{Cu}<1.32$ \\
Disordered isoferroplatinum & $\mathrm{Pt}_{3}-{ }_{x} \mathrm{Fe}$ & $0>Q>0.5$ & $2.68>\mathrm{Pt}>2.4,1.32<\mathrm{Fe}+\mathrm{Cu}<1.6$ \\
Disordered tetraferroplatinum & $\mathrm{Pt}_{1+} \mathrm{Fe}$ & $0>Q>0.5$ & $2.4>\mathrm{Pt}>2.25,1.6<\mathrm{Fe}+\mathrm{Cu}<1.75$ \\
Ordered tetraferroplatinum & $\mathrm{PtFe}$ & $0.5>Q>1$ & $2.25>\mathrm{Pt}>1.74,1.75<\mathrm{Fe}+\mathrm{Cu}<2.26$ \\
Disordered tetraferroplatinum & $\mathrm{Pt}_{1}-{ }_{z} \mathrm{Fe}$ & $0>Q>0.5$ & $1.74>\mathrm{Pt}>1.36,2.26<\mathrm{Fe}+\mathrm{Cu}<2.64$ \\
Disordered $\mathrm{PtFe}_{3}$ & $\mathrm{Pt}_{1+u} \mathrm{Fe}_{3}$ & $0>Q>0.5$ & $1.36>\mathrm{Pt}>1.18,2.64<\mathrm{Fe}+\mathrm{Cu}<2.82$ \\
Disordered tulameenite & $\mathrm{Pt}_{2} \mathrm{FeCu}_{1}-v$ & $0>Q>0.5$ & $2.25>\mathrm{Pt}>1.6,1.75<\mathrm{Fe}+\mathrm{Cu}<2.4,0.25<\mathrm{Cu}<0.5$ \\
Ordered tulameenite & $\mathrm{Pt}_{2} \mathrm{FeCu}$ & $0.5>Q>1$ & $2.25>\mathrm{Pt}>1.4,1.75<\mathrm{Fe}+\mathrm{Cu}<2.6,0.5<\mathrm{Cu}<1.5$ \\
\hline
\end{tabular}

The distinction between ordered $(Q>0.5)$ and disordered $(Q<0.5)$ phases is defined by the order parameter $Q$, which is calculated as the mid-point between the appropriate stoichiometric composition and the structural change indicated by a minimum in the solidus shown in Fig. 6 . This offers a range of compositions on either side of the stoichiometric composition which is used here to illustrate the ordered phase. Outside of this range, the phase is described as disordered for the purpose of this illustration. $Q$ is shown above the phase diagram on Fig. 6 . To compare the phases, all of them are calculated with 4 atoms/unit cell as $\mathrm{Pt}_{3} \mathrm{Fe}, \mathrm{Pt}_{2} \mathrm{Fe}_{2}, \mathrm{PtFe}_{3}$, and $\mathrm{Pt}_{2} \mathrm{FeCu}$. See text for further details

these alloys displays this variation between specific stoichiometric compositions having an ordered structure, e.g., $\mathrm{Pt}_{3} \mathrm{Fe}, \mathrm{PtFe}$, and $\mathrm{PtFe}_{3}$, separated by intermediate disordered compositions (Fig. 6). The range of compositions of the alloys in these samples reveals a pattern of compositional changes from the fresh to the altered rocks and saprolite indicative of a sequence of alteration.

\section{Discussion}

\section{Geochemistry - the mobility of Pt, Pd, and Au}

The location and age of the Freetown Intrusion indicate an origin associated with the opening of the Atlantic (Wells 1962; Beckinsale et al. 1977; Chalokwu et al. 1995). In this respect, it can be compared with the better exposed and extensively studied intrusions of the North Atlantic of which Skaergaard and Kap Edvard Holm are prime examples (e.g., Nielsen et al. 2015; Andersen 2006; Arnason and Bird 2000; Nielsen and Brooks 1995). In those intrusions, erosion has been by mechanical means (glacial action, freeze/thaw, etc.), and their PGM have not been exposed to tropical weathering. The Freetown Intrusion has undergone extensive erosion and weathering over more than $30 \mathrm{Ma}$ and, in recent times at least, weathering has been beneath a cover of tropical rainforest.

The trench dug to investigate the weathering has revealed a saprolite profile containing many partly weathered corestones to a depth of about 2 m over bedrock. The centers of the corestones appear to be less weathered than the rocks exposed at the surface (Fig. 3). The surface rocks typically do not exceed $200 \mathrm{ppb} \mathrm{Pt}$. Assays of the corestones show higher Pt assays (198-363 ppb $\mathrm{Pt})$ although there are very low values of $\mathrm{Pd}(<5-11 \mathrm{ppb} \mathrm{Pd})$ and $\mathrm{Au}$ is below detection ( $3 \mathrm{ppb}$ ). The $\mathrm{Pt} / \mathrm{Pd}$ and $\mathrm{Pt} / \mathrm{Au}$ ratios are, therefore, remarkably high relative to many intrusions. It is unclear if this is a primary feature or if there has been some leaching of $\mathrm{Pd}$ and $\mathrm{Au}$ from the exposed rocks. Particular samples from the Kap Edvard Holm intrusion show very similar Pt,
$\mathrm{Pd}$, and $\mathrm{Au}$ values to those described here although these are not typical (Arnason and Bird 2000). It is notable that the Monts de Cristal complex, Gabon, also has high $\mathrm{Pt} / \mathrm{Pd}$ and $\mathrm{Pt} / \mathrm{Au}$ ratios with Pt 10-150 ppb, Pd 1-15 ppb, and Au 1-2 ppb and an absence of magmatic sulfides (Maier et al. 2015; Barnes et al. 2016). This complex is very different in age ( $2770 \mathrm{Ma})$, in the presence of chromite, and in the occurrence as dismembered blocks within the granitic gneisses of the Congo Craton. However, it does seem possible that the high $\mathrm{Pt} / \mathrm{Pd}$ and $\mathrm{Pt} / \mathrm{Au}$ ratios of the Freetown mineralization could be primary.

The geochemistry of the rocks and saprolites indicates several contrasting processes (Fig. 8). The mineralized rocks from the trench contain 198-363 ppb Pt and 5-11 ppb Pd (Table 1). The saprolite immediately adjacent to these rocks at a depth of $1.1 \mathrm{~m}$ contains less $\mathrm{Pt}(147-271 \mathrm{ppb} \mathrm{Pt})$ but similar or slightly higher amounts of Pd (10-11 ppb Pd) than the adjacent mineralized rocks. The spheroidal weathering textures surrounding the corestones show that there has been no physical movement of the saprolite at this depth which has been formed by in situ alteration. The Pt and Pd in the saprolite have clearly been derived from weathering of the rocks. Relative to an isocon (Fig. 8b) with a slope of 1 (representing no change caused by weathering), $\mathrm{Fe}$ and $\mathrm{Al}$ are higher in the saprolite compared with the rocks. This is reasonable because further alteration leads to development of a Fe-rich laterite approaching a bauxitic composition (Barber 1962; Duchaufour 1982). Ti is not static in this environment but is elevated as is typical of this type of weathering (Malpas et al. 2001) and V follows $\mathrm{Ti}$. In the saprolite $\mathrm{Ca}, \mathrm{Na}$, and $\mathrm{Mg}$ are almost completely leached following complete breakdown of plagioclase and olivine. $\mathrm{K}$ and Au show less change and a variable behavior, the latter probably due to the results being very close to the detection limit. The lower Pt values in the lower saprolite compared with the mineralized rocks show that there has been a loss of about one third of the Pt and that the loss of Pt is greater in the upper saprolite. In contrast, the comparable Pd values in the lower saprolite compared with the mineralized rocks show 


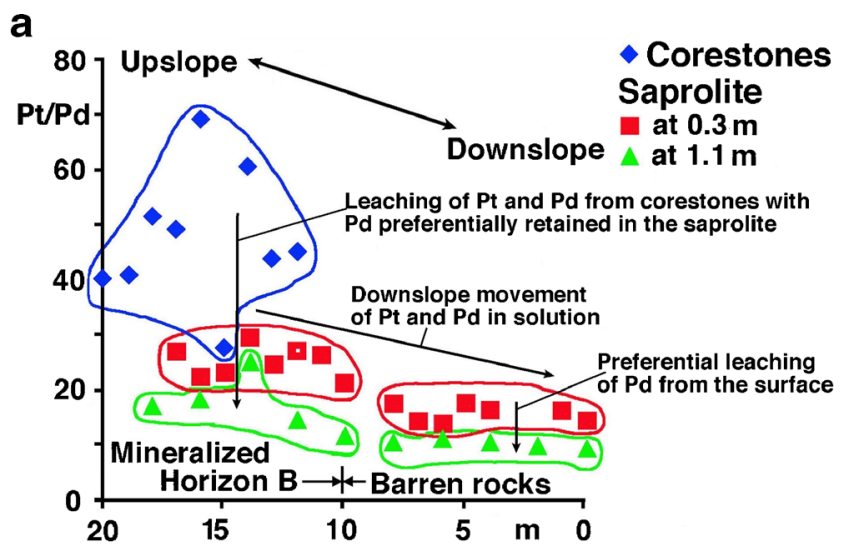

b

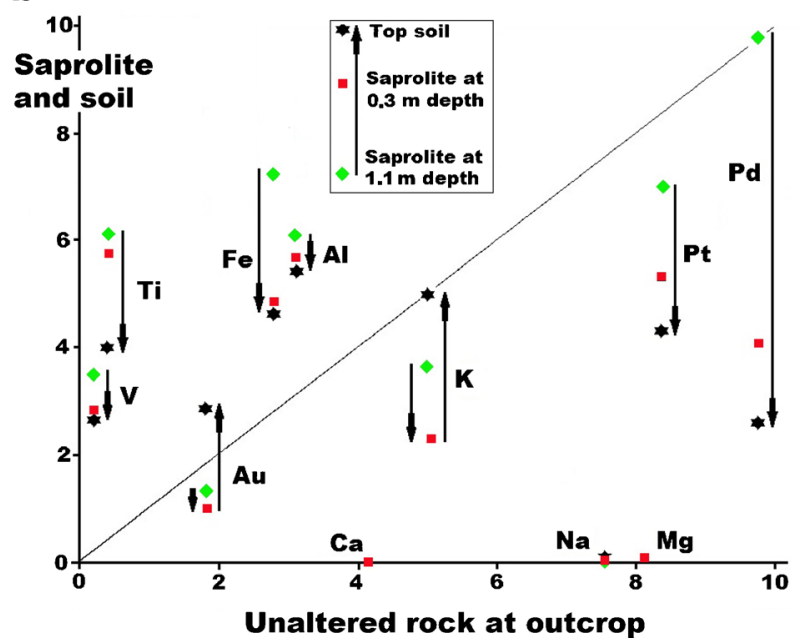

Fig. 8 a The variation of the $\mathrm{Pt} / \mathrm{Pd}$ ratio in corestones and saprolite at the mineralized Horizon B and in the saprolite over the barren rocks stratigraphically beneath Horizon B. Pt and Pd are below the detection limit in the barren rocks so no $\mathrm{Pt} / \mathrm{Pd}$ ratio is presented for these rocks. $\mathbf{b}$ Isocon diagram following Grant (2005) showing the variation with progressive weathering of $\mathrm{Pt}, \mathrm{Pd}$, and $\mathrm{Au}$ relative to the major elements at Horizon B (see Bowles 2000b; Bowles et al. 2013). The isocon has a slope of 1 representing no change due to weathering. Rocks: average of eight outcrop samples. Lower saprolite: average of five saprolite samples. Upper saprolite: average of ten saprolite samples. Soil: average of five surface soil samples

that Pd has been retained in the lower saprolite but leached to a greater extent than Pt from the upper saprolite.

The rocks of the unmineralized footwall rocks down slope of the mineralized rocks do not report Pt or Pd values above the detection limit (10 and $5 \mathrm{ppb}$, respectively, Table 1) apart from a single sample that contains $54 \mathrm{ppb} \mathrm{Pt}$ and no detectable Pd. The saprolite at a depth of $1.1 \mathrm{~m}$ surrounding these corestones also contains spheroidal weathering textures and is considered to have formed in situ so there has been no downslope slumping of loose material from the mineralized horizon. The upper and lower saprolite here contains much higher Pt and Pd values (98-120 ppb Pt and 9-11 ppb Pd) than the corestones which it surrounds. The presence of Pd and Pt down slope of the mineralized horizon can be explained as down slope movement of the Pt and Pd in solution. Particulate PGM liberated by the weathering are unlikely to have been transported any appreciable distance in any significant quantities into the unmineralized zone by water seeping through the saprolite.

The upper saprolite ( $0.3 \mathrm{~m}$ depth) contains less Pt and Pd than the lower saprolite $(1.1 \mathrm{~m})$ both over the mineralized horizon (103-178 ppb Pt and <5-7 ppb Pd) and over the unmineralized footwall rocks (87-116 ppb Pt and $<5-8 \mathrm{ppb} \mathrm{Pd}$ ). The lower Pt and Pd values in the upper saprolite compared with the lower saprolite suggest that the reduction in both $\mathrm{Pt}$ and $\mathrm{Pd}$ is an indication of surface leaching, probably due to the high rainfall.

$\mathrm{The} \mathrm{Pt} / \mathrm{Pd}$ ratio in the fresh, mineralized corestones (28-69) is lower in the adjacent mineralized saprolite (15-25) but rises in the upper saprolite (22-30). The $\mathrm{Pt} / \mathrm{Pd}$ ratios decrease down slope but the difference between upper (14-21) and lower (10-12) saprolite is maintained (Fig. 8). At each stage, the Pt and Pd appear to be behaving independently.

These four processes; weathering of $\mathrm{Pt}$ and $\mathrm{Pd}$ from the rocks into the lower saprolite, downslope movement through undisturbed saprolite, surface leaching, and independent movement of Pt and Pd are all consistent with movement of these metals in solution.

Despite the low Au concentrations in the rocks (all below the detection limit of $3 \mathrm{ppb} \mathrm{Au}$ ), just detectable $\mathrm{Au}$ ( $3 \mathrm{ppb} \mathrm{Au})$ in one deeper saprolite sample and $\mathrm{Au}(3-9 \mathrm{ppb} \mathrm{Au})$ in four adjacent near-surface saprolite samples indicates that a small proportion of $\mathrm{Au}$ is present in the system. The fact that the $\mathrm{Au}$ is reported in adjacent samples indicates that this is not a spurious result and may show that $\mathrm{Au}$ was present but has been leached more effectively than either Pt or Pd. The Au has accumulated in the down slope saprolite. These observations coincide with experience elsewhere; $\mathrm{Pd}$ and $\mathrm{Au}$ move readily in solution under surface conditions with Pt less mobile (Fuchs and Rose 1974; Wood 1991).

\section{The primary PGM and their alteration in weathered rocks}

The PGM in the rocks are small $(0.1-7 \mu \mathrm{m})$. PtS, and a smaller proportion of $\mathrm{Pt}_{3} \mathrm{Fe}$, dominate the fresh centers of the corestones; other PGM are scarce. Primary PtS and $\mathrm{Pt}_{3} \mathrm{Fe}$ within the weathered corestones develop altered rims of " $\mathrm{Pt}_{2} \mathrm{Fe}$ " to $\mathrm{PtFe}$ alloys that are often further altered to $\mathrm{Pt}-\mathrm{Fe} \pm \mathrm{Cu}$-bearing alloys and oxides. Their alteration textures can form corona or symplectic textures. PtS has provided the Pt supply for Pt-rich flame-like networks extending into the surrounding sulfides. These alteration textures are more common in the more weathered parts of the corestones, where irregular-shaped $\mathrm{Pt}-\mathrm{Fe} \pm \mathrm{Cu}$ alloys dominate the PGM assemblage. Only a few PGM have been located in the saprolite, and these are $\mathrm{Cu}$-poor PtFe and disordered $\mathrm{PtFe}_{3}$.

The weathering process results in loss of sulfur from the $\mathrm{PtS}$ and BMS, Pt-Fe alloys becoming more Fe rich, and $\mathrm{Cu}$ increasing in the Pt-Fe alloys from the freshest rocks to the weathered corestone rims and then decreasing in saprolite. 
The Pt-Fe alloys are more ordered in the freshest rocks $\left(\mathrm{Pt}_{3} \mathrm{Fe}\right)$ and then pass through disordered $\left(\mathrm{Pt}_{3} \mathrm{Fe}\right.$ and $\left.\mathrm{PtFe}\right)$ into ordered $\mathrm{PtFe}$ in the weathered zones of the corestones and into disordered $\mathrm{PtFe}_{3}$ in the saprolite (Fig. 6). The existence of ordered and disordered phases with a range of compositions is relevant to consideration of the genesis of these PGM. At magmatic temperatures, with greater mobility of the metals, there is a preference towards forming Pt-rich alloys with stoichiometric compositions having a restricted compositional range and an ordered structure. The presence of an almost continuous range of compositions, including the presence of disordered phases, suggests that subsolidus formation occurred under conditions of restricted mobility of $\mathrm{Pt}$ and $\mathrm{Fe}$. These lower temperature $\mathrm{Pt}-\mathrm{Fe}$ alloys were, therefore, formed from the Pt and Fe derived from the immediate locality of formation, where $\mathrm{Fe}$ is much more abundant than Pt, giving rise to more Fe-rich alloys.

\section{The similarity to other occurrences}

Altered PGM have been reported elsewhere. They often show textures such as oscillatory growth normal to mineral surfaces, voids, or symplectic textures, and they may form oxides or hydroxides (Burgath 1988; Cassedanne and Alves 1992; Augé and Legendre 1994; Cabral et al. 2008; Ndjigui and Bilong 2010; Suárez et al. 2010). These occurrences are commonly reported from areas that are, or have been, subjected to tropical weathering.

A particularly clear example is the oxidation of the Main Sulfide Zone (MSZ) of the Great Dyke, Zimbabwe (Oberthür et al. 2003a, b, 2013). The climate of Zimbabwe is drier ( $\sim 1000 \mathrm{~mm} /$ year) than that of the Freetown Peninsula with savanna or subtropical dry forest rather than tropical rainforest and the PGM in the Great Dyke are concentrated into more sulfiderich zones compared with the sulfide-poor, disseminated occurrence of the PGM in Freetown. However, the weathering regime has led to a similar sequence of alteration of the PGM. The MSZ is well known underground as a result of mining activity and economic concentrations of PGE; $\mathrm{Ni}$ and $\mathrm{Cu}$ are restricted to sulfide disseminations in bronzitite (Oberthür et al. 2003a). Underground, the mineral assemblage has not been weathered and the PGM consist of Pt/Pd bismuth tellurides (71\%) sperrylite $(11 \%)$, cooperite + braggite $(11 \%)$, and sulfarsenides $(2 \%)$ with rare sulfides and alloys. The same horizon extends to the surface, outcropping as oxidized MSZ in which sperrylite (58\%) and cooperite-braggite (35\%) remain but the bismuth tellurides have largely been destroyed. Relict bismuth tellurides (3.3\%) and porous $\mathrm{Pt}-\mathrm{Fe}$ alloys $(3.6 \%)$ are surrounded by inhomogeneous Pt and Pd oxides or hydroxides (Oberthür et al. 2003b). Overall, there has been a significant loss of Pd. A large proportion of the Pt (about 70\%) and most of the Pd observed in the assay of the outcropping oxidized MSZ are not found in particulate form and have been described as "missing" (Evans and Spratt 2000). Careful study by Oberthür et al. (2003b) has shown that rare, larger PGM grains do exist and that the apparently missing PGE could be explained by the presence of occasional larger primary grains not found by the chance sampling of multiple thin sections. The overall weathering process is similar to that in Freetown marked by oxidation, modification of the mineral assemblage and the separation of $\mathrm{Pt}$ and $\mathrm{Pd}$.

\section{The lack of PGM in the saprolite and leaching of PGE}

The PGM located in the saprolite from the trench are small and scarce, and they are insufficient to account for the assay values. There is a similar question of apparently missing Pt and Pd to that reported for the oxidized MSZ of the Great Dyke as summarized above. Can this be explained by the presence of rare secondary nuggets or relict large primary PGM not revealed by the sections examined? It is not possible to rule out something which is yet to be found. There are three lines of evidence indicating that the presence of rare large PGM is not a significant factor: (i) nearly 200 additional sections have been examined by microscopy, SEM, or microprobe in the course of the study of the mineralogy of the Freetown PGE-bearing rocks as well as those described here and by Bowles et al. (2013). No PGM have yet been found that are larger or different in mineralogy from those described. (ii) Of 1529 assays, 143 samples containing significant $\mathrm{Pt}$ and $\mathrm{Pd}$ values have been re-assayed and details of 7 representative re-assays were given by Bowles et al. (2013). These results include nine assays of duplicate samples from the original hand specimens plus eight assays with eight re-assays following re-sampling of the same outcrops. In all cases, the results are repeatable within reasonable limits. No rare high values of Pt or Pd occur in any of these assays which would indicate the presence of a single large PGM. This is the behavior of rocks containing fine-grained and evenly disseminated PGM, not that of rocks containing occasional much larger PGM. (iii) Any calculation to compare the assay values with the PGM that have been located will be approximate and dependent upon several assumptions. However, such an attempt, converting the PGM areas measured in section to a volume (assuming them to be spherical), assuming an average density and PGE content and relating that to the rock assays values and the weight of rock in the top $3 \mu \mathrm{m}$ of the sections has been undertaken (Table 2). The result is that the PGM can account for $77 \%$ of the PGE in the fresh parts of the corestones, $35 \%$ of the PGE in the weathered parts of the corestones, $15 \%$ of the PGE in the saprolitic rims, and $9 \%$ of the PGE in the saprolite. These figures clearly show a steady decrease in the PGE budget between the "findable" PGM in fresh rock with an increase in missing PGE as weathering progresses. The absolute values are very approximate; it is the relative values that are relevant, and they show a roughly twofold decrease in accountable PGE with each step (from fresh rock, to weathered rock, to highly weathered rim, and to saprolite) of the weathering process. 
It appears likely that the missing Pt and Pd may be adsorbed onto the secondary minerals in the saprolite as PGE oxides, PGE hydroxides, or organometallic compounds. Fixation of PGE and associated base metals by Fe oxides and sheet silicates is a common process in oxidizing environments during weathering of host sulfides. It has been described from the oxide zones of the Sakhara and Elizavet deposits in the Urals (Talovina and Lazarenkov 2001), the Great Dyke (Oberthür et al. 2003a, b; Oberthür and Melcher 2005; Locmelis et al. 2010), and the Aguablanca deposit, Spain (Suárez et al. 2010, 2011). The evidence presented here shows that the PGM have undergone alteration and that there is a progression of the degree of alteration and the type of mineral assemblage from the fresh rocks through more weathered rocks and into the saprolite. The alteration takes the form of oxidation with an initial loss of the sulfides. These changes are mirrored by the whole rock geochemistry that shows $\mathrm{Pt}$ and $\mathrm{Pd}$ in the saprolite moving independently down slope over barren horizons (Figs. 3 and 8). Weathering over a long period of time in an area of very high rainfall may be sufficient to account for these processes.

Only rare, small $(1-3 \mu \mathrm{m}) \mathrm{Pt}-\mathrm{Fe}$ alloys have been located in the saprolite. They are predominantly the most disordered alloys (Figs. 5 and 6). PGM trapped in aggregates within the saprolite show indistinct mineral boundaries accompanied by reaction zones of Pt-bearing $\mathrm{Fe}$ oxides indicating local release and redeposition of Pt (Fig. 4p). The leaching process observed in this study is consistent with that experienced beneath organic horizons in humid areas with high rainfall (i.e., Alexander and Cady 1962; Butt and Zeegers 1992; Aleva 1994; Butt et al. 1997). The climate of the Freetown peninsula has produced a cover of tropical rainforest that consists of broad-leafed trees with undergrowth. The forest floor is covered by leaf litter and decaying plant matter with an active insect and microbial population producing a wealth of organic compounds which must include humic and fulvic acids. Practical laboratory studies have shown that Pt and Pd can be taken into solution by these acids at about $25^{\circ} \mathrm{C}$ (Bowles et al. 1994b, 1995). The affinity of Pt for organic materials was known in 1827 (Zeise 1831), and the high mobility of Pd in the organic cycle has been widely described (i.e., Fuchs and Rose 1974; Wood 1991; Hattori and Cameron 2004). It is likely that the rich organic matter has played a part in weathering the PGM of the Freetown Peninsula (Bowles et al. 1994a, b, 1995). Formation of saprolite is isovolumetric with as much as half of the rock mass lost by leaching. The product has an open fabric that continues to occupy the original rock volume and allows water to circulate easily. Roots are able to penetrate the saprolite providing both additional organic components and water access (Stolt and Baker 1994; Fookes 1997). The presence of active organic compounds is likely to have aided the breakdown of the primary PGM and the movement of the PGE in solution in ground water maybe as PGE-organic compounds. Bacterially mediated transformation of the PGM may well be a significant factor (Reith et al. 2016).

\section{Conclusions}

This study has extended our understanding of the occurrence of PGM in fresh rocks from the PGE-enriched layer known as Horizon B in the Freetown Igneous Complex and the alteration of the PGM assemblage during the weathering of the rock to form saprolite. The nature of the alteration of the PGM and the location of that alteration in relation to weathering of the host rock is now clear.

The earliest alteration of the PGM may have begun in the fresh rocks with loss of Pt- and Pd-bearing cooperites. That Pdrich minerals may have existed is suggested by the low proportion of Pd relative to Pt in comparison with similar rocks found in other intrusions. There is now no textural evidence that Pdrich phases were originally present although a few Pd-bearing PGM were located in a nearby outcrop by Bowles et al. (2013) in the freshest rocks from Freetown. PGE-sulfide minerals such as cooperite, malanite, $\mathrm{Pt} \pm \mathrm{Rh}$-Ir-sulfides and laurite in the fresh rocks have been destroyed over about $10 \mathrm{~cm}$ in the transition from fresh rock to weathered rock and into the weathered rim of the corestones. The destruction is marked by the development of filamentous Pt in host sulfides such as chalcopyrite or weathered pentlandite and by the production of symplectic intergrowths of Pt-Fe alloy and Pt-oxides near grain boundaries. Isoferroplatinum has lost $\mathrm{Pt}$ and gained $\mathrm{Fe}$ and sometimes $\mathrm{Cu}$ within the $10 \mathrm{~cm}$ between fresh rock and the weathered rim. This has produced tetraferroplatinum and intermediate disordered non-stoichiometric alloys that may contain some $\mathrm{Cu}$. The PGE-bearing sulfides and their host $\mathrm{Cu}$ sulfides have been completely destroyed. In the saprolite, only tetraferroplatinum and the disordered alloys remain, and these are now free of $\mathrm{Cu}$. Tulameenite in the fresh rocks remains in the weathered rock and appears to increase in proportion in the weathered rim. This apparent increase is because the other PGM have been largely destroyed and the tulameenite is the last of the primary PGE phases to survive. It does not survive into the saprolite.

The Pt and Pd liberated by the destruction of the PGM have moved through the saprolite. The saprolite has retained the rock fabric and therefore this movement can probably only have been in solution. The most obvious conclusion is that the $\mathrm{Pt}$ and Pd have entered the saprolite down slope from the mineralized horizon carried by the ground water into the saprolite covering the unmineralized rocks. There is some evidence that $\mathrm{Au}$ has also moved in the same direction and that $\mathrm{Pt}$ and $\mathrm{Pd}$ have been leached from the near surface saprolite. The Pt and Pd have been transported independently downslope.

Acknowledgements We thank Drs. R.S. García and J. Sangüesa (SGIker, University of the Basque Country) for their technical support and the Department of Education, Universities and Research of the Basque Government (refs. BFI-2011-254 and IT762-13) for their funding of SS. Golden Prospect Mining Co. Ltd. funded the fieldwork and assays. The fieldwork was achieved with the cheerful help of the people of York, Sierra Leone. 
Open Access This article is distributed under the terms of the Creative Commons Attribution 4.0 International License (http:// creativecommons.org/licenses/by/4.0/), which permits unrestricted use, distribution, and reproduction in any medium, provided you give appropriate credit to the original author(s) and the source, provide a link to the Creative Commons license, and indicate if changes were made.

\section{References}

Aleva GJJ (1994) Laterites. Concepts, geology, morphology and chemistry. In: Creutzberd D (ed) International soil reference and information Centre (ISRIC). Wageningen, The Netherlands $169 \mathrm{p}$

Alexander LT, Cady JG (1962) Genesis and hardening of laterite in soils. Soils Conservation Service, United States Department of Agriculture, Washington D.C. Technical Bulletin No. 1282, 90 p.

Andersen JCØ (2006) Postmagmatic sulphur loss in the Skaergaard intrusion: implications for the formation of the Platinova reef. Lithos 92:198-221

Arnason JG, Bird DK (2000) A gold- and platinum-mineralized layer in gabbros of the Kap Edvard Holm Complex: field, petrologic, and geochemical relations. Econ Geol 95:945-970

Augé T, Legendre O (1994) Platinum-group element oxides from the Pirogues Ophiolitic Mineralization, New Caledonia: origin and significance. Econ Geol 89:1454-1468

Barber MJ (1962) A report in the prospecting for gold, platinum and molybdenum carried out during 1961-1962 on behalf of the Sierra Leone Government: Freetown, Sierra Leone State Development, Company Limited, $34 \mathrm{p}$.

Barkov AY, Fleet ME, Nixon GT, Levson V (2005) Platinum-group minerals from five placer deposits in British Columbia, Canada. Can Miner 43:1687-1710

Barnes SJ, Fisher LA, Godel B, Maier WD, Paterson D, Howard DL, Ryan CG, Laird JS (2016) Primary cumulus platinum minerals in the Monts de Cristal Complex, Gabon: magmatic microenvironments inferred from high-resolution X-ray fluorescence microscopy. Contrib Mineral Petrol 171:23

Beckinsale RD, Bowles JFW, Pankhurst RJ, Wells MK (1977) Rubidiumstrontium age studies and geochemistry of acid veins in Freetown complex, Sierra Leone. Min Mag 41:501-511

Bowles JFW (1977) A method of tracing the temperature and oxygenfugacity histories of complex magnetite-ilmenite grains. Min Mag 41:103-109

Bowles JFW (1978) The geochemical role of primary copper-sulfur mineralization in the crystallization of the Freetown (Sierra Leone) layered gabbro. Min Mag 42:111-116

Bowles JFW (1981) The distinctive suite of platinum-group minerals from Guma Water, Sierra Leone. Bulletin de Minéralogie 104:478-483

Bowles JFW (1986) The development of platinum-group minerals in laterites. Econ Geol 81:1278-1285

Bowles JFW (1990) Platinum-iron alloys, their structural and magnetic characteristics in relation to hydrothermal and low-temperature genesis. Miner Petrol 43:37-47

Bowles JFW (1995) The development of platinum-group minerals (PGM) in laterites: mineral morphology. Chronique Rech Min 520:55-63

Bowles JFW (2000a) Prassoite, vysotskite and keithconnite from the Freetown layered complex, Sierra Leone. Miner Petrol 68:75-84

Bowles JFW (2000b) A primary platinum occurrence in the Freetown layered intrusion, Sierra Leone. Mineral Deposita 35:583-586

Bowles JFW, Atkin D, Lambert JLM, Deans T, Phillips R (1983) The chemistry, reflectance and cell-size of the erlichmanite $\left(\mathrm{OsS}_{2}\right)$ laurite $\left(\mathrm{RuS}_{2}\right)$ series. Min Mag 47:465-471
Bowles JFW, Giże AP, Cowden A (1994a) The mobility of the platinumgroup elements in the soils of the Freetown peninsula, Sierra Leone. Can Miner 32:957-967

Bowles JFW, Giże AP, Vaughan DJ, Norris SJ (1994b) The development of platinum-group minerals in laterites; initial comparison of the organic and inorganic controls. Trans Inst Mining Metall (Section B, Applied Earth Sci) 103:B53-B56

Bowles JFW, Giże AP, Vaughan DJ, Norris SJ (1995) Organic controls on platinum- group element (PGE) solubility in soils: initial data. Chronique Rech Min 520:65-73

Bowles JFW, Lyon IC, Saxton JM, Vaughan DJ (2000) The origin of platinum group minerals from the Freetown intrusion, Sierra Leone, inferred from osmium isotope systematics. Econ Geol 95:539-548

Bowles JFW, Prichard HM, Suárez S, Fisher PC (2013) The first report of platinum-group minerals in magnetite-bearing gabbro, Freetown Layered Complex, Sierra Leone: occurrences and genesis. Can Miner 51:455-473

Burgath K-P (1988) Platinum-group minerals in ophiolitic chromitites and alluvial placer deposits, Metatus-Bobaris Area, Southeast Kalimantan. In: Prichard HM, Potts PJ, Bowles JFW, Cribb SJ (eds) Proceedings of the symposium geo-platinum 87. Elsevier Applied Science, London, pp 343-403

Butt CRM, Lintern MJ, Anand RR (1997) Evolution of regoliths and landscapes in deeply weathered terrain - implications for geochemical exploration. In: Gubins AG (ed) Proceedings of Exploration 97: Fourth Decennial International Conference on Mineral Exploration, paper 40, pp. 323-334

Butt CRM, Zeegers H (eds) (1992) Regolith exploration geochemistry in tropical and subtropical terrains. Handbook of exploration geochemistry 4. Elsevier, Amsterdam $607 \mathrm{p}$

Cabral AR, Galbiatti HF, Kwitko-Ribeiro R, Lehmann B (2008) Platinum enrichment at low temperatures and related microstructures, with examples of hongshiite $(\mathrm{PtCu})$ and empirical ' $\mathrm{Pt}_{2} \mathrm{HgSe}_{3}$ ' from Itabira, Minas Gerais, Brazil. Terra Nov. 20:32-37

Cabri LJ, Feather CE (1975) Platinum-iron alloys: a nomenclature based on a study of natural and synthetic alloys. Can Miner 13:117-126

Cabri JL, Harris DC, Weiser TW (1996) Mineralogy and distribution of platinum-group mineral (PGM) placer deposits of the world. Explor Min Geol 5:73-167

Cassedanne JP, Alves JN (1992) Palladium and platinum from Córrego Bom Sucesso, Minas Gerais, Brazil. Mineral Rec 23:471-474

Chalokwu CI, Seney PJ, Wurie CA, Bersh M (1995) Petrology of the Freetown layered complex, Sierra Leone: part 1, stratigraphy and mineral-chemical evidence for multiple magma injections. Int Geol Rev 37:230-253

Dixey F (1920) Notes on lateritization in Sierra Leone. Geol Mag 57:211-221

Duchaufour F (1982) Pedology, pedogenesis and classification. Translated by TR Paton, George Allen and Unwin, London, $460 \mathrm{p}$

Evans DM, Spratt J (2000) Platinum and palladium oxides/hydroxides from the Great Dyke, Zimbabwe, and thoughts on their stability and possible extraction. In: Rammlmair D et al (eds) Applied mineralogy in research, economy, technology. Ecology and Culture. AA Balkema, Rotterdam, pp 289-292

Evstigneeva TL (2009) Phases in the Pt-Fe system. Vestnik Otdelenia nauk o Zemle RAN 1:1-2

Fookes PG (ed) (1997) Tropical Residual Soils. Geological Society Professional Handbooks, The Geological Society, London, $184 \mathrm{p}$

Fuchs WA, Rose AW (1974) The geochemical behavior of platinum and palladium in the weathering cycle in the Stillwater complex, Montana. Econ Geol 69:332-346

Grant JA (2005) Isocon analysis: a brief review of the method and applications. Phys Chem Earth 30:997-1004

Gregory S (1952) The raised beaches of the Peninsular area of Sierra Leone. Trans Papers, Inst British Geographers, Publication No 31, 15-22. 
Hargraves RB, Briden JC, Daniels BA (1999) Paleomagnetism and magnetic fabric in the Freetown complex, Sierra Leone. Geophys J Int 136:705-713

Hattori KH, Cameron EM (2004) Using the high mobility of palladium in surface Media in exploration for platinum group element deposits: evidence from the lac des Iles region, northwestern Ontario. Econ Geol 99:157-171

Hughes RH, Hughes JS (1992) A Directory of African Wetlands. IUCN, Gland, Switzerland and Cambridge, UK/UNEP, Nairobi, Kenia/ WCMC, Cambridge, UK, $820 \mathrm{p}$.

Junner NR (1929) Report of the geological department for part of the year 1927 and for the year 1928. Government printer, Freetown, $17 \mathrm{p}$

Junner NR (1930) Geology and mineral resources of Sierra Leone. Mining Mag 42:73-82

Junner NR, Harwood HF (1930) The norite of Sierra Leone, British West Africa. 15th International Geological Congress, Pretoria, South Africa, 1929. Compte Rendu 2:417-433

Locmelis M, Melcher F, Oberthür T (2010) Platinum-group element distribution in the oxidized Main Sulfide Zone, Great Dyke, Zimbabwe. Mineral Deposita 45:93-109

Maier WD, Rasmussen B, Fletcher IR, Godel B, Barnes SJ, Fisher LA, Yang SH, Huhma H, Lahaye Y (2015) Petrogenesis of the $\sim 2.77 \mathrm{Ga}$ Monts de Cristal complex, Gabon: evidence for direct precipitation of Pt-arsenides from basaltic magma. J Petrol 56:1285-1308

Malitch KN, Thalhammer OAR (2002) Pt-Fe nuggets derived from clinopyroxenite-dunite massifs, Russia: a structural, compositional and osmium-isotope study. Can Miner 40:395-418

Malpas J, Duzgoren-Aydin NS, Aydin A (2001) Behaviour of chemical elements during weathering of pyroclastic rocks; Hong Kong. Environ Internat 26:359-368

Morel SW (1979) Geology and mineral resources of Sierra Leone. Econ Geol 74:1563-1576

Ndjigui P-D, Bilong P (2010) Platinum-group elements in the serpentinite lateritic mantles of the Kongo-Nkamouna ultramafic massif (Lomié region, South-East Cameroon). J Geochem Explor 107:63-76

Nielsen TFD, Brooks CK (1995) Precious metals in magmas of East Greenland: factors important to the mineralization in the Skaergaard intrusion. Econ Geol 90:1911-1917

Nielsen TFD, Andersen JCØ, Holness MB, Keiding JK, Rudashevsky NS, Rudashevsky VN, Salmonsen LP, Tegner C, Veksler IV (2015) The Skaergaard PGE and gold deposit: the result of in situ fractionation, sulphide saturation, and magma chamber-scale precious metal redistribution by immiscible Fe-rich melt. J Petrol 56:1643-1676

Nixon GT, Cabri JL, Laflamme JHG (1990) Platinum-group-element mineralization in lode and placer deposits associated with the Tulameen Alaskan-type complex, British Columbia. Can Miner 28:503-535

Nosé Y, Kushida A, Ikeda T, Nakajima H, Tanaka K, Numakura H (2003) Re-examination of phase diagram of Fe-Pt system. Mater Trans 44: 2723-2731

Oberthür T, Melcher F (2005) Behaviour of PGE and PGM in the supergene environment: a case study of persistence and redistribution in the Main Sulfide Zone of the Great Dyke, Zimbabwe. In: Mungall JE (ed) Exploration for Platinum-Group Element Deposits. Mineral Association of Canada, Short Course 35:97-111

Oberthür T, Weiser TW, Gast L, Kojonen K (2003a) Geochemistry and mineralogy of platinum-group elements at Hartley Platinum Mine, Zimbabwe part 1. Primary distribution patterns in pristine ores of the Main Sulfide Zone of the Great Dyke. Mineral Deposita 38:327-343

Oberthür T, Weiser TW, Gast L (2003b) Geochemistry and mineralogy of platinum-group elements at Hartley Platinum Mine Zimbabwe. Part 2: supergene redistribution in the oxidized Main Sulfide Zone of the Great Dyke, and alluvial platinum-group minerals. Mineral Deposita 38:344-355

Oberthür T, Weiser TW, Melcher F, Gast L, Wöhrl C (2013) Detrital platinum-group minerals in rivers draining the Great Dyke, Zimbabwe. Can Miner 51:197-222
Okamoto H (1993) Fe-Pt (iron-platinum). In: H Okamoto (ed) Phase diagrams of binary iron alloys. ASM International, Materials Park, $\mathrm{OH}$, pp. 330-336

Okamoto H (2004) Fe-Pt (iron-platinum). J Phase Equilibria and Diffusion 25:395

Osaka K, Sakai D, Takama T (2002) In situ X-ray measurement of orderdisorder transition temperature of Fe-rich Fe-Pt alloys. Japanese $\mathrm{J}$ Applied Phys 41:L155-L157

Prichard HM, Lord RA (1994) Evidence for the mobility of PGE in the secondary environment in the Shetland ophiolite complex. Transactions Institution Mining Metallurgy 103:B79-B86

Pollett JD (1931) Platinum mining in Sierra Leone. Engineering Mining World 2:747-748

Pollett JD (1951) The geology and mineral resources of Sierra Leone. Colonial geology and mineral. Resources 2:3-28

Reith F, Zammit CM, Shar SS, Etschmann B, Bottrill R, Southam G, Ta C, Kilburn M, Oberthür T, Ball AS, Bruggers J (2016) Biological role in the transformation of platinum-group mineral grains. Nat Geosci 9:294-298

Rudashevsky NS, Mochalov AG, Men'shikov YP, Shumskaya NI (1983) Ferronickelplatinum $\mathrm{Pt}_{2} \mathrm{FeNi}-\mathrm{a}$ new mineral species. Zap Vsesoyusn Min Obshcht 112:487-494 (in Russian)

Shahmiri M, Vaughan DJ, Murphy S (1986) Observation of twin-related order domains in $\mathrm{CuFePt}_{2}$. Physica status solidi A-applied. Research 95:63-72

Stolt MH, Baker JC (1994) Strategies for studying saprolite and saprolite genesis. In: Cremeens DL, Brown DL, Huddleston JH (eds) Whole regolith pedology. Soil Science Society of America, Special Publication 34, Madison 1-19

Suárez S, Nieto F, Velasco F, Martín FJ (2011) Serpentine and chlorite as effective Ni-Cu-sinks during weathering of the Aguablanca sulphide deposit (SW Spain). TEM evidence for metal-retention mechanisms in sheet-silicates. Eur J Mineral 23:179-196

Suárez S, Prichard HM, Velasco F, Fisher PC, McDonald I (2010) Alteration of platinum-group minerals and dispersion of platinumgroup elements during progressive weathering of the Aguablanca $\mathrm{Ni}-\mathrm{Cu}$ deposit, SW Spain. Mineral Deposita 45:331-350

Talovina IV, Lazarenkov VG (2001) Distribution and genesis of platinum group minerals in nickel ores of the Sakhara and Elizavet deposits in the Urals. Lithol Miner Resour 36:116-122

Tolstykh ND, Foley JY, Sidorov EG, Laajoki KVO (2002) Composition of the platinum-group minerals in the Salmon River placer deposit, Goodnews Bay, Alaska. Can Miner 40:463-471

Weiser TW, Bachmann H-G (1999) Platinum-group minerals from the Aikora River area, Papua New Guinea. Can Miner 37:1131-1145

Wells MK (1962) Structure and petrology of the Freetown layered basic complex of Sierra Leone. Overseas Geology and Mineral Resources. Bulletin Supplement, 4:115 p

Wells MK, Bowles JFW (1981) The textures and genesis of metamorphic pyroxene in the Freetown intrusion. Min Mag 44:245-255

Wood SA (1991) Experimental determination of the hydrolysis constants of $\mathrm{Pt}^{+2}$ and $\mathrm{Pd}^{+2}$ at $25{ }^{\circ} \mathrm{C}$ from the solubility of $\mathrm{Pt}$ and $\mathrm{Pd}$ in aqueous hydroxide solutions. Geochim Cosmochim Acta 55:1759-1767

Zaccarini F, Pushkarev E, Garuti G, Krause J, Dvornik GP, Stanley C, Bindi L (2013) Platinum group minerals (PGM) nuggets from alluvial-eluvial placer deposits in the concentrically zoned mafic-ultramafic Uktus complex (Central Urals, Russia). Eur J Miner 25:519-531

Zeise WC (1831) I.Von der wirkung zwischen platinchlorid und alkohol, und den dabei entstehenden neuen substanzen. II. Gekohlenwasserstofftes chlorplatin-ammoniak. Annalen der Physik und Chemie (Poggendorff) 21:497-549

Zhernovsky IV, Mochalov AG, Rudashevsky NS (1985) Phase inhomogeneity of isoferroplatinum enriched in iron. Dokl Akad Nauk SSSR 283:196-200 